Universidade de Brasília

Faculdade de Tecnologia

Departamento de Engenharia Florestal

Caracterização das propriedades anatômicas, química e densidade da espécie Bambusa vulgaris Schrad. ex J.C. Wendl., para a produção de celulose Kraft com diferentes cargas de Álcali.

Aluno: Eraldo Antonio Bonfatti Júnior

Matrícula: 05/81224

Orientador: Prof. Dr. Joaquim Carlos Gonçalez

Co-orientador: Prof. Dr. Francides Gomes da Silva Júnior

Trabalho Final de Curso apresentado ao Departamento de Engenharia Florestal como requisito parcial para obtenção do grau de Engenheiro Florestal.

Brasília - DF, dezembro de 2010 
Universidade de Brasília

Faculdade de Tecnologia

Departamento de Engenharia Florestal

\title{
Caracterização das propriedades anatômicas, química e densidade da espécie Bambusa vulgaris Schrad. ex J.C. Wendl., para a produção de celulose Kraft com diferentes cargas de Álcali.
}

\author{
Aluno: Eraldo Antonio Bonfatti Júnior \\ Matrícula: 05/81224 \\ Trabalho Final de Curso apresentado ao Departamento de Engenharia Florestal \\ como requisito parcial para obtenção do grau de Engenheiro Florestal. \\ Menção: \\ Aprovada por:
}

Prof. Dr. Joaquim Carlos Gonçalez

Orientador - EFL/UnB

Prof. Dr. Ailton Teixeira do Vale

Examinador Interno - EFL/UnB

Dr. Fernando Nunes Gouveia

Examinador Externo - Pesquisador - LPF/SFB/MMA

Brasília - DF, dezembro de 2010 
Ao meu "Avohai", Marciano José de Paula, in memorian.

Aos meus pais, Eraldo Antonio Bonfatti e Valentina Maria de Paula, pelo amor incondicional e apoio aos meus estudos.

Á minha Namorada, Danila Bacani, pelo amor, carinho e paciência. 


\section{AGRADECIMENTO}

À Brasília por me acolher e me ensinar paciência e tolerância.

À Universidade de Brasília e seu Departamento de Engenharia Florestal.

Em especial, ao Professor Dr. Joaquim Carlos Gonçalez pela oportunidade de crescimento, ensinamentos e orientação.

Aos meus amigos Alexandre, Bob e Fábio por mostrar-me a fonte da juventude; sem vocês meu espírito teria a mesma idade do meu corpo. Igual aos meus amigos Biscoito, Angelo, Luis, Iara, Criscian Kellen, Celina, Juliano, Marcão, Mayara, Érica, Fabrícia, Luiz, Layse e Thaís e a todos os amigos conquistados nessa empreitada de cinco anos, minha eterna gratidão.

Ressalto agradecimento especial ao Fábio pela grande ajuda na análise estatística e ao Biscoito pela formatação desse trabalho.

Ao Ever, amigo, companheiro e o melhor vizinho que um solitário pode ter.

À amiga Tuka, pelo exemplo de motivação e sempre perdoar a minha ausência.

À Empresa Júnior de Consultoria Florestal - ECOFLOR, onde me transformei em Engenheiro Florestal, e todos os seus associados.

À "Gloriosa" Escola Superior de Agricultura "Luiz de Queiroz" e ao Departamento de Ciências Florestais.

Ao Professor Dr. Francides Gomes da Silva Júnior pela orientação técnica e ensinamento prático.

Aos amigos do Laboratório de Química Celulose e Energia "Luiz Ernesto George Barrichelo" (LQCE-LEGB), Tiago, Fava, Raphael, Cris, Regina, Marina, Adriana, José Martins e Lívia.

Ao Professor Dr. Mario Tomazello Filho e a técnica Maria do Laboratório de Anatomia da Madeira (LAM) do Departamento de Ciências Florestais da USP/ESALQ, onde foi realizada a análise anatômica.

Ao Professor Dr. Geraldo Bortoletto Júnior e o técnico Alex do Laboratório de Ensaios Mecânicos de Madeira e Derivados (LEMMAD) do Departamento de Ciências Florestais da USP/ESALQ, que cederam os equipamentos para a classificação e dimensionamento dos cavacos.

À mestranda Júlia, por compartilhar os bons e maus momentos em Piracicaba. 
À república esalquiana K-labouço, pelo acolhimento, festas e diversão.

Ao Conselho Nacional de Desenvolvimento Científico e Tecnológico pela bolsa concedida.

A todos que direto ou indiretamente colaboraram para realização deste sonho. 


\section{RESUMO}

\section{Caracterização das propriedades anatômicas, química e densidade da espécie Bambusa vulgaris Schrad. ex J.C. Wendl., para a produção de celulose Kraft com diferentes cargas de Álcali.}

O presente estudo teve como objetivo avaliar o comportamento do Bambusa vulgaris Schrad. ex J.C. Wendl. com 2 anos de idade oriundos de plantios comerciais no Maranhão - Brasil, no processo Kraft de polpação sobre diferentes cargas de álcali, além da caracterização anatômica, química e densidade básica. Os resultados obtidos mostram que a matéria-prima apresentou valores típicos para a espécie em questão no que diz respeito à densidade básica, dimensões e índices morfológicos das fibras e composição química. No cozimento Kraft as cargas de álcali aplicadas variaram entre 10 e $24 \%$, em intervalos de $2 \%$. Os parâmetros analisados foram: rendimento bruto, rendimento depurado, teor de rejeitos, número Kappa, viscosidade, álcali ativo residual, $\mathrm{pH}$ residual, sólidos totais no licor negro, lignina residual e ácidos hexenurônicos. Para todos estes parâmetros as variações da carga de álcali foram notadas nos resultados. Para o rendimento bruto os valores médios variaram entre 34,6 e 52,25\%. Para o rendimento depurado os valores médios variaram entre 34,61 e 51,24\%. A semelhança dos resultados entre rendimento bruto e rendimento depurado pode ser explicada pelo baixo teor de rejeitos e boa impregnação do licor na madeira durante a polpação. $\mathrm{O}$ conteúdo de rejeitos foi baixo para todas as cargas de álcali sendo quase nulas a partir de $14 \%$ de álcali ativo. Para o número Kappa os valores médios variaram entre 80,82 e 8,78 . Para a viscosidade os valores médios variaram entre 57,34 e $19,12 \mathrm{~cm}^{3} / \mathrm{g}$. Para as cargas de 10 a $12 \%$ o álcali ativo residual foi nulo, isso mostra que faltou álcali no cozimento com essas cargas, e entre 14 e $24 \%$ os valores médios variaram entre 1,81 e $12,99 \%$. O pH residual, teor de sólidos totais no licor negro, lignina residual e ácidos hexenurônicos aumentaram com o aumento das cargas de álcali.

Palavras-chave: Bambusa vulgaris; processo polpação Kraft; cargas de álcali. 


\section{ABSTRACT \\ Characterization of the anatomical, chemical and density of Bambusa vulgaris Schrad. ex JC Wendl. for the production of Kraft pulp with different alkali charges.}

The present study had as objective to evaluate the behavior of Bambusa vulgaris Schrad. ex J.C. Wendl. with 2 years old originating commercial plantings in Maranhão - Brazil, in the kraft pulping process on different alkali charges, besides the anatomical characterization, chemistry and basic density. The obtained results show that the raw material presented typical values for the species in subject in what says respect to the basic density, dimensions and morphologic indexes of the fibers and chemical composition. In the kraft cooking the alkali charges applied varied between 10 and 24\%, at $2 \%$ intervals. The parameters analyzed were: total yield, screened yield, kappa number, viscosity, residual active alkali, residual $\mathrm{pH}$, total solids in black liquor, residual lignin and hexenuronic acids. For all these parameters the variations in alkali charges were noted in the results. For the total yield the average values varied between 34.6 and $52.25 \%$. For the screened yield the average values varied between 34.61 and $51.24 \%$. The similarity of results between total yield and screened yield can be explained by low content of tailings and good impregnation of liquor into the wood during the pulping. The content of tailings was low for all alkali charges being almost zero from $14 \%$ of active alkali. For the kappa number the average values varied between 80.82 and 8.78 . For the viscosity the average values varied between 57.34 and $19.12 \mathrm{~cm}^{3} / \mathrm{g}$. For charges $10-12 \%$ the residual active alkali was zero, it shows that lacked alkali in cooking with these charges, and between 14 and $24 \%$ the average values varied between 1.89 and $12.99 \%$. The residual $\mathrm{pH}$, total solids in black liquor, residual lignin and hexenuronic acids increased with increasing alkali charges.

Keywords: Bambusa vulgaris; Kraft pulping process; alkali charges. 


\section{SUMÁRIO}

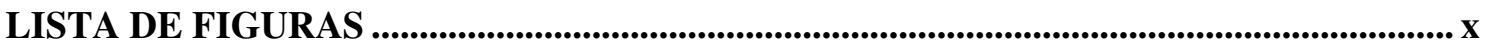

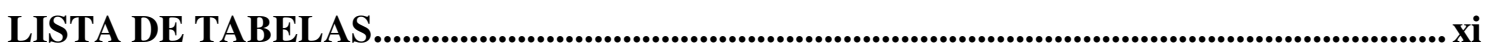

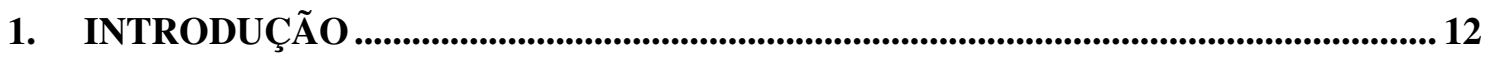

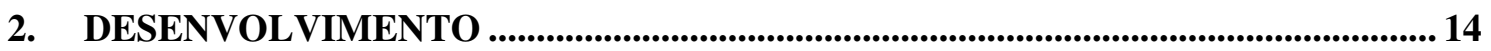

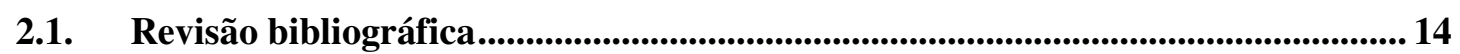

2.1.1. Matérias-primas para produção de polpas celulósicas ...................................... 14

2.1.1.1. Bambu ................................................................................................................... 15

2.1.1.1.1. Bambusa vulgaris Schrad ex J.C. Wendl.......................................................... 17

2.2. Produção de polpa celulósica ........................................................................... 18

2.2.1. Características tecnológicas.......................................................................19

2.2.1.1. Processo de polpação Kraft ............................................................................ 19

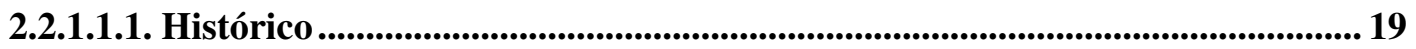

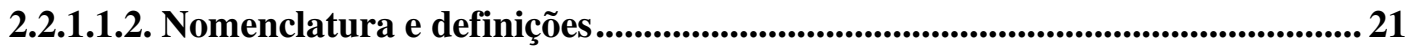

2.2.1.1.3. Descrição do processo Kraft ............................................................................................... 22

2.2.1.1.4. Química do processo Kraft............................................................................................. 23

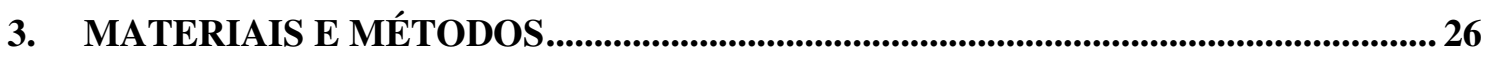

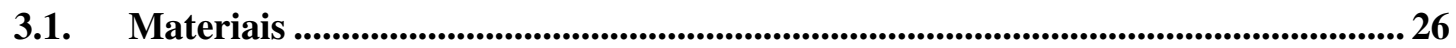

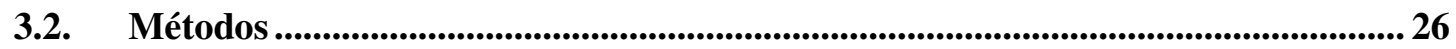

3.2.1. Classificaçã̃o dos cavacos............................................................................................... 27

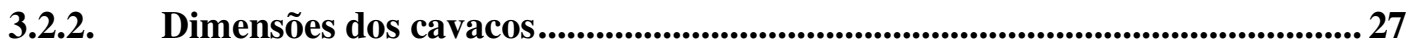

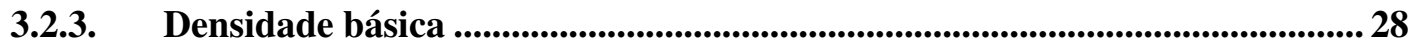

3.2.4. Caracterização anatômica da madeira.......................................................................... 28

3.2.5. Composição química da madeira ................................................................................29

3.2.6. Processo de polpação............................................................................................................ 30

3.2.7. Análise do licor negro ................................................................................................... 31

3.2.8. Análise da polpa .......................................................................................................... 31

3.2.9. Análise estatística ............................................................................................................. 32

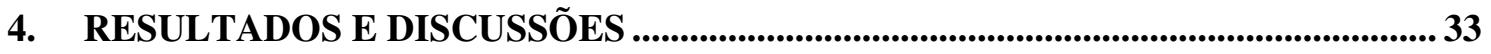

4.1. Caracterização da matéria-prima........................................................................................ 33

4.1.1. Classificação dos cavacos................................................................................................... 33

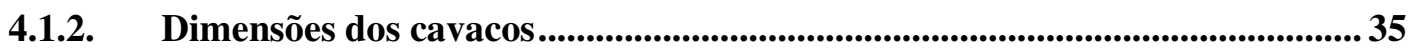

4.1.3. Densidade básica dos cavacos.....................................................................38

4.1.4. Caracterização anatômica da madeira.................................................................... 39 
4.1.5. Composição química da madeira...................................................................................... 41

4.2. Análise do licor negro .................................................................................................................. 43

4.2.1. Análise estatística .................................................................................................................... 43

4.2.2. Álcali ativo resídual.......................................................................................4 43

4.2.3. Teor de sólidos totais..................................................................................................... 44

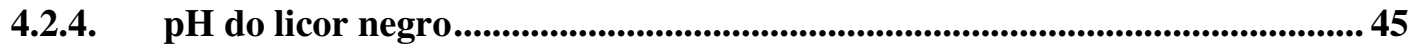

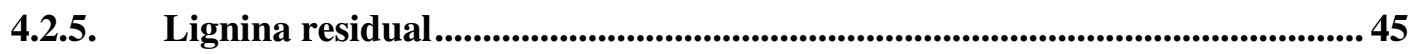

4.3. Análise da polpa ......................................................................................................... 47

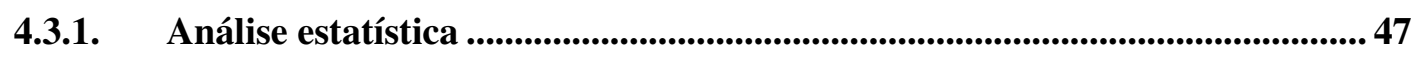

4.3.2. Rendimento ........................................................................................................................ 47

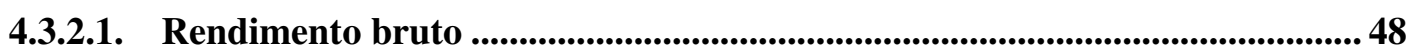

4.3.2.2. Rendimento depurado............................................................................................ 48

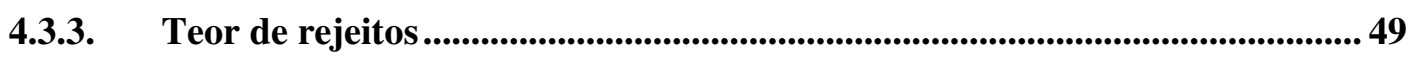

4.3.4. Ácidos hexenurônicos.....................................................................................50

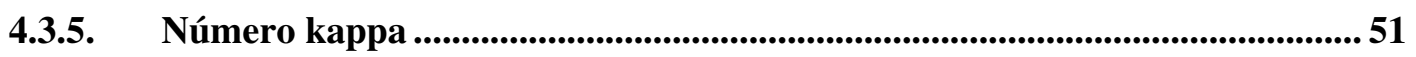

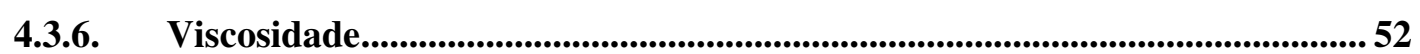

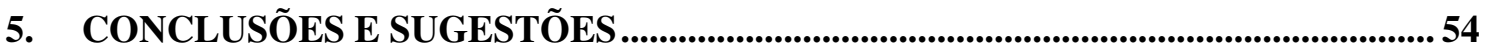

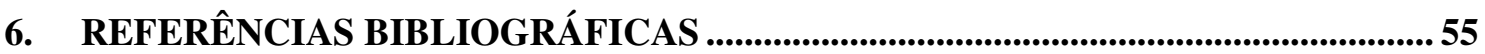

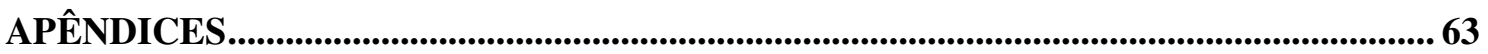

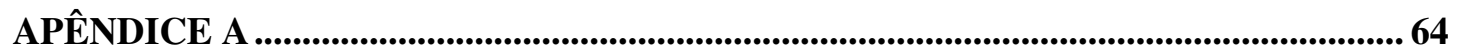

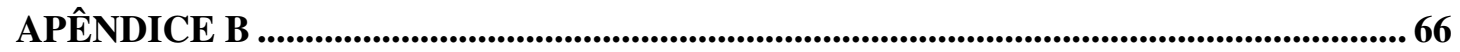

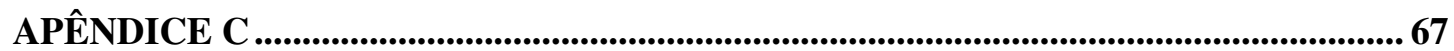




\section{LISTA DE FIGURAS}

Figura 1: Localização do município Coelho Neto/MA - Brasil............................................... 26

Figura 2: Classificador elétrico com peneiras vibratórias no LQCE......................................... 27

Figura 3: Digestor rotativo aquecido eletronicamente RegMed no LQCE............................. 30

Figura 4: Classificaçãa dos cavacos em classes de largura média. ............................................ 34

Figura 5: Classificação dos cavacos em classes de largura média..............................................34

Figura 6: Distribuição de cavacos por classes de espessura. ........................................................... 36

Figura 7: Distribuição de cavacos por classes de largura..........................................................36

Figura 8: Distribuição dos cavacos por classes de comprimento.............................................. 37

Figura 9: Álcali Ativo Residual (g/l) / Álcali Ativo, Base NaOH (\%)...................................... 44

Figura 10: Teor de Sólidos (\%) / Álcali Ativo, Base NaOH (\%) ................................................. 44

Figura 11: pH residual / Álcali Ativo, Base $\mathrm{NaOH}(\%)$............................................................ 45

Figura 12: Lignina Residual (g/l) / Álcali Ativo, Base $\mathrm{NaOH}(\%)$....................................... 46

Figura 13: Rendimento Bruto (\%) / Álcali Ativo, Base NaOH (\%) .......................................... 48

Figura 14: Rendimento Depurado (\%) / Álcali Ativo, Base NaOH (\%) .............................. 49

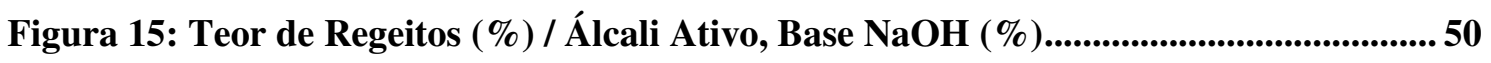

Figura 16: Ácidos Hexenurônicos $\mu \mathrm{mol}$ g-1 / Álcali Ativo, Base $\mathrm{NaOH}$ (\%)......................... 51

Figura 17: Número kappa / Álcali Ativo, Base $\mathrm{NaOH}(\%)$............................................................. 52

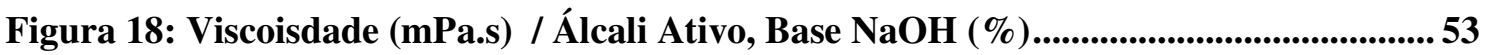




\section{LISTA DE TABELAS}

Tabela 1: Condições para curva de cozimento do processo de polpação Kraft. 30

Tabela 2: Parâmetros determinados nos licores negros resultantes do processo Kraft. .... 31

Tabela 3: Parâmetros determinados nas polpas celulósicas do processo Kraft. ................... 31

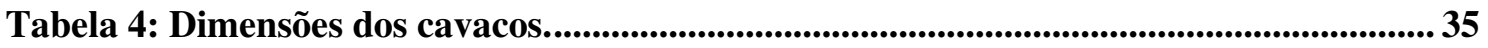

Tabela 5: Resultado das dimenções e relações morfológicas das fibras de B. vulgaris....... 39

Tabela 6: Classificação de Runkel ................................................................................................. 40

Tabela 7: Resultados da comparação química da madeira de B. vulgaris .............................. 41

Tabela 8: Análise estatística para os resultados dos parâmetros do licor residual .............. 43

Tabela 9: Análise estatística para os resultados dos parâmetros da polpa celulósica.......... 47 


\section{INTRODUÇÃO}

O Brasil é o $4^{\circ}$ maior produtor mundial de celulose com uma produção de 13,5 milhões de toneladas de celulose em 2009. A renda do setor representa $1 \%$ do PIB nacional, sendo o $1^{\circ}$ no ranking mundial na produção de celulose de fibra curta branqueada de eucalipto (BRACELPA, 2010). Não obstante, o mercado mundial de polpa celulósica demanda não apenas polpa de fibra curta, mas também polpas de fibra longa, utilizadas principalmente para produção de papéis de elevada resistência, destinados a embalagens. Os papéis produzidos a partir de polpas de fibra longa representam um pouco mais da metade de todo o consumo mundial de papel, atualmente a importação de celulose de fibra longa no Brasil é de 323.000 ton./ano (BRACELPA, 2010), gerando um déficit na balança comercial brasileira de US\$ 274.000.000/ano (IPEF, 2010; cotação de US\$ 849,69/ton. de celulose de fibra longa na União Européia). Esses números deixam claro o enorme potencial não aproveitado por alguns países do hemisfério sul na produção de polpa celulósica de fibra longa, em especial o Brasil pela sua amplitude territorial e edafo-climática.

O Pinus taeda L. é a espécie mais explorada para a produção de celulose de fibra longa no Brasil, suas exigências de clima e solo restringem sua produção aos três estados da Região Sul do País (KLEINE, 2002; BRACELPA, 2010).

Não obstante o bambu já é reconhecimento por ser uma fonte alternativa para a produção de celulose. Estudos das propriedades químicas, anatômicas e testes de resistência de folhas de celulose demonstraram o grande potencial técnico do bambu para a produção de papéis tipo Kraft. Como desvantagem o bambu apresenta alto teor de extrativos e sílica, o que causa uma diminuição no rendimento. No entanto, essa perda no rendimento pode ser compensado por sua alta produtividade (GOMIDE et al, 1981). Porém, apesar do elevado potencial das espécies de bambu no Brasil, são poucas as pesquisas dirigidas para as áreas silvicultural e tecnológica (BRITO et al, 1987).

Segundo Azzini et al. (1987) vários estudos já vem demonstrando a potencialidade do bambu para a produção de celulose. Os autores também destacam que os vários aspectos favoráveis na utilização do bambu estão relacionados, principalmente, com suas características agronômicas, aliadas ao elevado comprimento de suas fibras celulósicas (1,65 a 3,43 mm), que ocupam uma posição intermediária entre as fibras de Eucalyptus spp. (1,0 mm) e as do Pinus spp. (3,5 mm), ou seja, fibras estreitas como 
Eucalyptus spp. e longas como as do Pinus spp, proporcionando um perfeito entrelaçamento e conferindo grande resistência aos produtos fabricados (CASTRO E SILVA, 2010), podendo-se inserir no mercado como substituto das fibras longas de pinus.

Segundo Gomide et al. (1981) a espécie mais utilizada no Brasil para fins industrias é o B. vulgaris, que apesar de muito espalhada pelo país é originária da China. Possui colmos grossos de cor verde. Cresce aproximadamente $35 \%$ mais rápido que a árvore que ocupa a segunda colocação em ritmo de crescimento (pau de balsa, Ochroma pyramidale (Cav. ex Lam.) Urb.), permitindo colheitas anuais ou bi-anuais e suporta até 100 cortes, sem necessidade de replantio (SBRT, 2009). É usado, principalmente para produção de polpa de papel, além de fonte de bebida alcoólica.

De acordo com Campanella et al. (2008) essa espécie produz matéria-prima para um dos melhores multifoliados do mundo. Várias indústrias de celulose e papel já iniciaram experiências industriais com a espécie, porém foram obrigadas a interromper principalmente por não haver plantações próprias.

Silva Jr \& McDONOUGH (2001) afirmam que como a principal característica do processo kraft é alta qualidade da celulose obtida. Esta qualidade é avaliada basicamente pelo nível de lignina residual (o número kappa), à medida que os carboidratos são discriminados (viscosidade), e pelas propriedades físico-mecânicas. No entanto, estas características podem ser alteradas por algumas variáveis do processo produtivo, tais como: álcali, tempo de cozimento e temperatura, entre outras coisas.

Este estudo teve como objetivos a caracterização anatômica, química e densidade básica da espécie Bambusa vulgaris Schrad. ex J.C. Wendl., com 2 anos de idade oriundos de plantios comerciais do estado do Maranhão - Brasil, bem como a fabricação e análise de celulose Kraft sob diferentes cargas de álcali. 


\section{DESENVOLVIMENTO}

\subsection{Revisão bibliográfica}

\subsubsection{Matérias-primas para produção de polpas celulósicas}

A produção de pasta celulósica baseia-se fundamentalmente em madeiras (cerca de $95 \%$ ), sendo o eucalipto a principal matéria-prima com $65 \%$, seguida pelo pinheiro com 30\%. Outras matérias-primas tais como sisal, rami, bagaço de cana, palhadas e bambu respondem por menos de 5\% do total (FUZETO, 2003).

Existem muitas pesquisas na busca de outras espécies para produção de celulose. Segundo Barrichelo \& Brito (1979), do ponto de vista tecnológico qualquer matériaprima fibrosa é possível de ser utilizada na produção de celulose. Porém, quando analisada sob o aspecto econômico uma série de fatores devem ser levados em consideração:

- percentagem de fibras;

- características anatômicas, físicas e químicas;

- quantidade disponível e em local da fácil acesso;

- possibilidade de regeneração a prazos curtos ou médios;

- custos relativamente baixos;

- existência de mercado para o tipo de celulose a ser produzida.

O mesmo autor afirma que de uma maneira geral, as matérias-primas vegetais podem ser classificadas como:

- fibras de sementes e frutos. (línter do algodão e palha de coco);

- fibras de folhas. (sisal, fórmio e abacaxi);

- fibras de madeira de:

- coníferas. (pinus);

- folhosas. Ex.: (eucalipto).

- fibras de floema de dicotiledôneas herbáceas. (crotalária, rami e juta).

- fibras vasculares de monocotiledôneas. (palhas de cereais bagaço de cana-deaçúcar e bambu). 
- fibras de estipes. (coqueiros e palmeiras).

A escolha por um tipo de material dependerá, das suas características intrínsecas, do processo de produção de celulose e do seu uso final.

O bambu, bem como outras espécies conhecidas como não arbóreas, vêm sendo valorizado pela indústria de celulose e papel, que está cada dia mais preocupada com o futuro do suprimento de matérias-primas para atender a crescente demanda mundial.

Embora algumas espécies de bambu representem, em alguns países como a Índia, o principal material fibroso utilizado na produção de celulose e papel é ainda pouco estudado, tanto em suas características agronômicas como tecnológicas (FERNANDÉZ, 2010).

\subsubsection{Bambu}

Em termos taxonômicos, segundo Pereira e Beraldo (2007), os bambus pertencem à família Poaceae (anteriormente Gramineae), subfamília Bambusoideae, tribos herbáceos (Olyreae) e lenhosos (Bambuseae). Essa subfamília possui aproximadamente 75 gêneros e 1250 espécies, ocorre naturalmente no mundo inteiro com exceção da Europa e representa uma matéria-prima de elevada importância, principalmente nos países asiáticos, onde é encontrado o maior número de espécies.

Espécies de bambu são encontradas em altitudes que variam de zero até 4800 metros. Os tons de cor são variados: preto, vermelho, azul, violeta, tendo o verde e o amarelo como principais. Resistem a temperaturas abaixo de zero e temperaturas tropicais. Crescem como pequenas gramíneas ou chegam a extremos de 40 metros de altura. No Brasil existem espécies nativas e exógenas (não-nativas). As nativas são cerca de 80 espécies diferentes, pertencentes a 10 gêneros (AZZINI et al., 1987).

O mesmo autor divide os bambus de acordo com a forma de desenvolvimento dos colmos: bambu em touceira ou bambu alastrante. No primeiro grupo, formado basicamente por espécies tropicais, os colmos encontram-se agrupados formando uma moita ou touça. No segundo grupo, de espécies de clima temperado, os colmos nascem isoladamente.

$\mathrm{O}$ crescimento do bambu ocorre de maneira diferente das árvores. Os colmos saem da terra com diâmetro e número de nós definidos e, em menos de 1 ano, atingem a 
altura máxima. Após o primeiro ano, os colmos vão amadurecendo, isto é, vão mudando suas características internas, tornando-se mais resistentes. (AZZINI et al., 1987).

De acordo com Liese (1999 apud VELEZ, 2001), o bambu representa o sustento de mais de um bilhão de pessoas, principalmente nas áreas rurais pobres de países em desenvolvimento da Ásia, América do Sul e Central. O bambu é um recurso natural que pode ser empregado em diversos usos: compensados de bambu são utilizados em paredes e pisos como revestimentos; sua polpa serve como matéria-prima na produção de papel e celulose; ele ainda é utilizado conjuntamente com o concreto na construção civil, entre outros usos. Alguns usos e espécies são destacados por Azzini et al. (1987), como:

- polpa celulósica: B. vulgaris, Phyllostachys bambusoides Siebold \& Zucc., Dendrocalamus giganteus Wall. ex Munro;

- álcool: B. vulgaris, Guadua flabellata E. Fourn., B. vulgaris var. vittata Rivière \& C. Rivière;

- alimentação: Phyllostachys sp., Dendrocalamus sp., Bambusa sp;

- ornamentação: B. gracilis Wall., P. nigra (Lodd. ex Lindl.) Munro, $P$. purpurata McClure, Thyrsostachys siamensis Gamble, Arundinaria amabilis McClure, Arundinaria sp;

- construção civil: Phyllostachys sp., Guadua sp., B. tuldoides Munro, D. giganteus.

Segundo o mesmo autor, no início da indústria de fabricação de papel, o bambu foi uma das primeiras matérias-primas fibrosas utilizadas, de acordo com Carvalho (1960) o bambu representou 17\% de toda a polpa no Brasil na década de 1960. Porém, devido a questões econômicas e de disponibilidade, foi substituído por espécies arbóreas nos países de clima temperado, onde se desenvolveu toda a tecnologia de produção de celulose e papel. Em 1988 a produção de polpa celulósica de bambu representava menos de um por cento do volume total produzido (D'ALMEIDA, 1988). Atualmente única empresa que utiliza essa matéria prima se localiza no município de Coelho Neto, no Maranhão, e tem produtividade de 56.000 ton./ano equivalente a 0,41\% da produção total (BRACELPA, 2010). 
Apesar da falta de conhecimentos tecnológicos específicos no que se refere ao processamento dessa espécie, o bambu oferece amplas possibilidades agronômicas por ser uma planta perene e apresentar altos índices de produção de biomassa por unidade de área.

Segundo Londono (1999), o Brasil conta com a maior diversidade e mais alto índice de florestas endêmicas de bambu em toda a América Latina: são 137 espécies, representando 32\% das espécies da América Latina, e 17 gêneros ou 85\%. Os estados de São Paulo, Minas Gerais, Santa Catarina, Bahia e Paraná, possuem a maior diversidade de florestas de bambu, sendo a Floresta Atlântica é a principal responsável por essa diversidade. Estudos relevantes vêm sendo desenvolvidos em alguns centros de pesquisas, e o interesse pela sua aplicação tem crescido. Entretanto, o seu potencial ainda é pouco explorado.

\subsection{Bambusa vulgaris Schrad ex J.C. Wendl.}

Segundo a Flora Brasiliensis (2010), Bambusa é um gênero botânico pertencente à família Poaceae (Gramineae), subfamília Bambusoideae, tribo Bambuseae. O gênero é constituído por aproximadamente 390 espécies de bambus, geralmente gigantes. Estas

espécies ocorrem na África, Ásia, Pacífico, América do Norte e América do Sul.

Segundo Pereira e Beraldo (2007), a altura dos colmos pode variar de 8-20 metros, o diâmetro dos mesmos varia de 6-15 centímetros e a espessura da parede de 715 milímetros com internós de 25-35 centímetros.

Quanto ao referente ao clima e solo, os mesmo autores afirmam que a espécie em questão tem aptidão de uma grande variedade: climas de trópicos úmidos, trópicos secos e semi-áridos e solos ricos, médios e pobres. Cresce ate 1500 metros de altitude, suportando uma temperatura mínima de ate $-2^{\circ} \mathrm{C}$. Como distribuição natural classificase como uma espécie pantropical. Seus usos mais comuns são construção, polpa e papel, cercas, moveis, andaimes, artesanato e produção de álcool.

Como uso potencial pode-se citar reabilitação de solos degradados e adaptação em áreas semiúmidas. $\mathrm{O}$ crescimento médio anual desta espécie atinge em média 22- 44 $\mathrm{m}^{3}$ /ha/ano, recomendando-se seu plantio em espaçamentos de $8 \mathrm{~m} \times 7 \mathrm{~m}$ (PEREIRA E BERALDO, 2007; MURAKAMI, 2007). Segundo Netto et al. (2008), o volume de 
massa seca produzido numa plantação de 3 anos de idade, com 5000 colmos por hectare é de 16300 kg/há. De acordo com Filho et al. (2004), a espécie Bambusa vulgaris possui $51,58 \%$ de carbono no peso total de sua biomassa, classificada como $\mathrm{C} 4$, de alta absorção de carbono, o que contribui para o equilíbrio ambiental.

Os colmos de bambu apresentam muitas aplicações rurais, além de possuir características de rápido crescimento em solos declivosos e pobres e eficiente controle da erosão. (BRITO; TOMAZELLO FILHO; SALGADO, 1987).

No Brasil, é a espécie que apresenta maiores áreas de plantio. A Região Nordeste tem a maior área plantada do mundo, com plantios distribuídos nos estados do Maranhão, da Paraíba e de Pernambuco. Portanto é, B. vulgaris, uma planta essencial ao desenvolvimento florestal do nordeste brasileiro, usada como matéria prima industrial para a produção e papel de fibra longa, que exibe maior resistência para uso em embalagens. No entanto, apesar do seu alto potencial produtivo, há poucas pesquisas em silvicultura e manejo (BRITO et al, 1986; BONILLA, 1991).

\subsection{Produção de polpa celulósica}

Segundo Gonçalez (2009) os processos de produção de celulose podem ser classificados de acordo com o tipo de energia utilizada.

São utilizadas energias:

- Mecânica;

- Térmica;

- Química;

- ou combinações destas.

Tipos de Processos:

- Mecânicos;

- Termo-Mecânicos;

- Químico-Mecânicos ou Mecano-Químicos;

- Químico-Termo-Mecânicos;

- Semi-Químicos; 
- Químicos.

Foelkel e Barrichelo (1975) em seus estudos indicam que existem diversos métodos propostos para a obtenção de celulose de bambus e que os principais são: processo soda, processo sulfato e processo sulfito neutro. As celuloses obtidas apresentaram rendimentos superiores a 50\%, alta resistência ao rasgo e razoáveis resistências à tração e ao arrebatamento quase próximas as apresentadas por polpas celulósicas derivadas de coníferas.

Gomide (1982), cita que a celulose de bambu é bem diferente das outras celuloses, tanto de fibras de madeiras como de não-madeiras, apresentando alta resistência ao rasgo, semelhante ou superior à de celulose kraft de coníferas, e resistência à tração e ao estouro também semelhantes às dessas celuloses. Devido à alta relação comprimento/diâmetro, as fibras de bambu apresentam alta flexibilidade e relativa maciez. São indicadas para a produção de vários tipos de papéis, como absorvente, embalagem, impressão e escrita. Apesar das vantagens agronômicas e tecnologias a produção de polpa celulósica a partir do bambu ainda pode ser considerada pequena. Esse fato pode ser explicado, entre outras razões, pela deficiência de informações técnico-científicas sobre a constituição química e anatômica do bambu e de conhecimentos tecnológicos referentes aos parâmetros de processamento industrial adequado para essa matéria-prima.

Gomide et al. (1981) em estudos experimentais realizados com a espécie $B$. vulgaris para a produção de papéis tipo kraft, concluiram que existe grande potencialidade desta espécie para a produção de papéis de altas resistências, comparáveis às obtidas em papéis produzidos com madeiras de Pinus elliottii Engelm.

\subsubsection{Características tecnológicas}

\subsubsection{Processo de polpação Kraft}

\subsection{Histórico}

O processo soda foi o primeiro método químico de polpação reconhecido com a utilização de uma solução alcalina forte de hidróxido de sódio para deslignificação de cavacos de madeira . Este precursor do processo kraft foi originalmente patenteado em 1854. Uma patente posterior, de 1865 , cobriu a incineração do licor de soda gasto para 
recuperação do álcali utilizado no processo. A primeira fábrica com processo soda que operou com sucesso entrou em operação em 1866. Atualmente poucas fábricas que operam o processo soda ainda se encontram em operação no mundo produzindo polpa de folhosas e matérias primas não lenhosas (KLOCK, 2010).

O crédito do desenvolvimento do processo kraft (sulfato) é dado a C.J. DAHL. Num esforço para encontrar um substituto para o dispendioso carbonato de sódio (cinza da soda) como o precursor do ciclo químico do processo soda, ele experimentou a adição de sulfato de sódio na fornalha de recuperação. $O$ sulfato foi quimicamente reduzido a sulfeto pela ação da queima do licor na fornalha. Subsequentemente DAHL descobriu que o sulfeto no licor de cozimento acelerou acentuadamente a deslignificação com produção de polpa mais resistente, obtendo patente para o processo em 1884 (D'ALMEIDA, 1988).

O novo processo de polpação foi primeiramente utilizado comercialmente na Suécia em 1885. As propriedades de resistência superiores foram reconhecidas e os novos tipos de papéis foram chamados papéis kraft ou fortes, já que kraft é a palavra alemã para forte. Segundo esse desenvolvimento muitas fábricas de soda, converteramse para o processo kraft de forma a competirem com outras que usavam o processo sulfito. Enquanto que a polpa sulfito era mais resistente, mais barata e mais clara em cor que a polpa soda, o processo kraft estreitou a margem em custo de produção e forneceu um produto mais resistente. A recuperação econômica dos produtos químicos de polpação era uma necessidade para o processo kraft para competir com o processo sulfito, o qual não requeria sistema de recuperação (KLOCK, 2010).

O grande impulso para domínio do processo kraft ocorreu na década de $30 \mathrm{com}$ introdução do sistema de recuperação de TOMLINSON, no qual a evaporação final e a queima do licor gasto foram combinados com a recuperação de calor e dos químicos numa mesma unidade do processo (KLOCK, 2010).

Finalmente, o desenvolvimento e utilização do branqueamento com dióxido de cloro por HOWARD RAPSON no final da década de 40 e início dos anos 50 levou a se encontrarem níveis da alvura comparáveis aos conseguidos com polpa sulfito (KLOCK, 2010). 


\subsection{Nomenclatura e definições}

Klock (2010) usa as seguintes nomenclaturas e definições:

- licor branco: contem os produtos químicos ativos de cozimento: hidróxido de sódio $(\mathrm{NaOH})$ e sulfeto de sódio $\left(\mathrm{Na}_{2} \mathrm{~S}\right)$, é usado para cozimento dos cavacos.

- licor negro residual: contem os produtos da reação da solubilização da lignina, é concentrado e queimado na caldeira de recuperação para fornecer uma pasta inorgânica de carbonato de sódio $\left(\mathrm{Na}_{2} \mathrm{CO}_{3}\right)$ e sulfeto de sódio, chamado em inglês de "SMELT".

O "SMELT" é dissolvido para formar o licor verde, que é reagido com óxido de cálcio $(\mathrm{CaO})$, cal virgem, para converter $\mathrm{Na}_{2} \mathrm{CO}_{3} \mathrm{em} \mathrm{NaOH}$ e regenerar o licor branco original.

A terminologia utilizada para caracterizar quimicamente os licores é definida por Klock (2010) na sequência a seguir:

- produtos químicos totais: são todos os compostos de sódio do licor, expressos como $\mathrm{Na}_{2} \mathrm{O}$

- álcali total ou álcali ativo titulável: inclui o hidróxido, sulfeto, carbonato e o sulfato de sódio, expresso como $\mathrm{Na}_{2} \mathrm{O}$.

- álcali ativo: inclui o hidróxido e o sulfeto de sódio, expresso como $\mathrm{Na}_{2} \mathrm{O}$. O álcali ativo é geralmente expresso em porcentagem sobre o peso absolutamente seco da madeira empregada.

- álcali efetivo: inclui $\mathrm{NaOH}+1 / 2\left(\mathrm{Na}_{2} \mathrm{~S}\right)$, expresso como $\mathrm{Na}_{2} \mathrm{O}$.

- atividade: é a relação porcentual entre o álcali ativo e o álcali total titulável.

Atividade $=(\mathrm{AA} / \mathrm{ATT}) \mathrm{x} 100$

- sulfidez: é a relação porcentual entre a quantidade de $\mathrm{Na}_{2} \mathrm{~S}$, expresso como $\mathrm{Na}_{2} \mathrm{O}$, e o álcali-ativo.

- causticidade: é a relação porcentual entre a quantidade de $\mathrm{NaOH}$, expressa como $\mathrm{Na}_{2} \mathrm{O}$, e o álcali total titulável.

- eficiência da caustificação: é a relação porcentual entre a quantidade de $\mathrm{NaOH}$ e as quantidades de $\mathrm{NaOH}+\mathrm{Na}_{2} \mathrm{CO}_{3}$, todos expressos como $\mathrm{Na}_{2} \mathrm{O}$. 
- eficiência de redução: é a relação porcentual entre a quantidade de $\mathrm{Na}_{2} \mathrm{~S}$ e as quantidades de $\mathrm{Na}_{2} \mathrm{~S}+\mathrm{Na}_{2} \mathrm{SO}_{4}$, todos expressos como $\mathrm{Na}_{2} \mathrm{O}$.

Existem discordâncias se o Álcali ativo (AA) ou o Álcali efetivo (AE) não há consenso sobre o qual é a melhor forma de mensuração da concentração química ativa para cozimento Kraft.

Embora tanto o $\mathrm{NaOH}$ (hidróxido de sódio) quanto o $\mathrm{Na}_{2} \mathrm{~S}$ (sulfeto de sódio) tomem parte na reação de cozimento, pode-se mostrar que o $\mathrm{NaOH}$ promove a principal força de reação, pois $\mathrm{o} \mathrm{Na}_{2} \mathrm{~S}$ hidrolisa em solução de forma representada na seguinte equação (1):

$$
\mathrm{Na}_{2} \mathrm{~S}+\mathrm{H}_{2} \mathrm{O} \rightarrow \mathrm{NaOH}+\mathrm{NaSH}
$$

Desta forma, apenas $1 / 2$ do $\mathrm{Na}_{2} \mathrm{~S}$ é realmente efetivo na determinação da cinética da reação.

\subsection{Descrição do processo Kraft}

De acordo com Klock (2010) no cozimento (ou digestão), o licor negro gasto é lavado da polpa e tratado numa sequiência para recuperação dos produtos químicos do cozimento e regeneração do licor de cozimento:

- processo de digestão pode ser em batelada ou contínuo. No cozimento por batelada o digestor é preenchido com cavacos e licor suficiente é adicionado para cobrilos.

- o conteúdo é aquecido de acordo com programa pré-estabelecido, usualmente por circulação forçada do licor de cozimento através de trocador de calor. O ar e outros gases não condensáveis são aliviados através de válvula de controle de pressão no topo do digestor.

- a temperatura máxima é atingida após 1 - 1,5 horas, o que permite o licor de cozimento impregnar os cavacos.

- o cozimento é então mantido a temperatura máxima (usualmente em torno de $170^{\circ}$ ) por cerca de $1-2$. 
- após o cozimento, o conteúdo é descarregado sob pressão em tanques, onde os cavacos amolecidos são desintegrados em fibras, os vapores resultantes são condensados em trocadores de calor onde água é aquecida para lavagem da polpa.

- em cozimentos contínuos, os cavacos passam primeiramente através de um vaso com vapor onde ar e outras substâncias não condensáveis são retirados. Os cavacos pré aquecidos e licor de cozimento entram no digestor contínuo, onde move-se através de uma zona de temperatura intermediária ( $115-120^{\circ}$ ), para permitir uma penetração ideal do licor nos cavacos.

- na medida em que a massa de cavacos move-se através do vaso de cozimento, a mistura é aquecida até a temperatura de cozimento, por circulação forçada do licor através do trocador de calor ou por injeção de vapor, e mantida nesta temperatura por 1 a 1,5 horas.

- seguindo a complementação do cozimento, licor quente gasto é extraído para um tanque de baixa pressão onde o vapor é gerado para uso no vaso de vapor .

- a polpa é usualmente esfriado abaixo de $100^{\circ} \mathrm{C}$ com licor frio para prevenir danos mecânicos às fibras.

- a polpa cozida é separada do licor negro num processo cuidadoso e controlado conhecido por lavagem do estoque marrom. O método mais comum emprega uma série de tambores lavadores a vácuo no sistema contra corrente, para permitir uma retirada do licor com o mínimo de diluição. Alguns digestores contínuos incorporam uma etapa de lavagem por difusão em conjunto com a extração do licor gasto e esfriamento da polpa. Segundo a lavagem a polpa é peneirada e limpa.

\subsection{Química do processo Kraft}

As reações que ocorrem no processo Kraft de polpação são complexas e não totalmente entendidas. Essencialmente, a lignina incrustada nos cavacos de madeira é quimicamente quebrada em fragmentos pelos íons hidroxil $(\mathrm{OH})$ e hidrosulfitos $\left(\mathrm{SH}^{-}\right)$ presentes no licor. Os fragmentos da lignina são então dissolvidos como íons fenolato ou carboxilato. Carboidratos, primariamente as polioses e de celulose, são também quimicamente atacadas e dissolvidas em alguma extensão (KLOCK, 2010). 
O mesmo autor afirma que durante um cozimento típico de polpa branqueável aproximadamente $80 \%$ da lignina, $50 \%$ das polioses e $10 \%$ da celulose são dissolvidas. Em condições ideais os fragmentos de lignina tomam parte em reações de condensação com próprios fragmentos ou com lignina não dissolvida e possivelmente até com carboidratos (D'ALMEIDA, 1988).

A lignina condensada é mais difícil de remover das fibras. Acredita-se que o íon hidrosulfeto reduz reações de condensação por bloqueamento dos grupos reativos. As duas forças propulsoras das reações para a polpação kraft são a concentração de álcali e temperatura (D’ALMEIDA, 1988).

Entre a faixa normal da temperatura de cozimento $\left(155-175^{\circ} \mathrm{C}\right)$, a taxa de deslignificação dobra para cada $10^{\circ} \mathrm{C}$ de aumento. Arbitrando-se um valor relativo de 1 para a taxa de reação a $100^{\circ} \mathrm{C}$, foi desenvolvido um fator para expressar o tempo de cozimento e a temperatura como a única variável (KLOCK, 2010).

Quando a taxa de reação relativa é plotada contra o tempo de cozimento em horas, a área sob a curva é definida como fator $\mathrm{H}$. $\mathrm{O}$ conceito do fator $\mathrm{H}$ tem sido largamente aplicado no controle de cozimento, mas é especialmente útil quando a temperatura varia durante o período de cozimento (D’ALMEIDA, 1988).

Segundo Klock (2010) a deslignificação durante o processo kraft ocorre em três fases distintas:

- a remoção inicial muito rápida de lignina é caracterizada como um processo de extração;

- seguindo-se como uma reação de primeira ordem ocorre a remoção da maior parte da lignina;

- remoção da lignina residual.

Tipicamente os cozimentos kraft são completados a um conteúdo de lignina residual de 4 - 5\% para coníferas e cerca de 3\% para folhosas, bem dentro da fase de deslignificação do grosso do conteúdo inicial de lignina. Se os cozimentos forem deixados por mais tempo a deslignificação residual ocorrerá a uma taxa bem menor. Sobrepondo-se às reações da lignina estão as reações com as polioses e celulose (KLOCK, 2010). 
O conteúdo de polioses é reduzido em aproximadamente $40 \%$ durante o estágio de extração do cozimento, já a lignina cerca de $20 \%$. A perda é causada pela dissolução dos carboidratos de baixo peso molecular, remoção de grupos ácidos e degradação pela chamada reação de "peeling” (KLOCK, 2010).

A perda relativamente baixa de celulose, cerca de $10 \%$ é explicada pela baixa acessibilidade dos íons $\mathrm{OH}$ nas regiões cristalinas da celulose. Os produtos das reações acídicas dos carbohidratos consomem a maior parte do álcali no licor de cozimento (D’ALMEIDA, 1988).

Durante a deslignificação ocorre também uma redução na viscosidade da polpa (uma medida de peso da celulose - peso molecular médio). Se é permitido que a viscosidade da polpa caia para um nível crítico, a resistência da polpa diminui drasticamente (D’ALMEIDA, 1988).

A manutenção da viscosidade da polpa é a principal razão para que o cozimento Kraft deva ser terminado a um ponto onde um teor substancial de lignina residual permaneça nas fibras (D'ALMEIDA, 1988).

Uma derivação denominada Fator - G (exatamente análogo ao fator $\mathrm{H}$ ) pode ser aplicada para a redução da viscosidade, por exemplo, espera-se que as combinações do tempo e temperatura que vão dar o mesmo Fator $G$ venham fornecer a produção de polpa com a mesma viscosidade. Desde que o fator $\mathrm{G}$ aumenta mais rapidamente com a temperatura que o fator $\mathrm{H}$, conclui-se que temperaturas de cozimento altas tem proporcionado maior efeito na redução de viscosidade. Esta é a principal razão porque evita-se temperaturas de cozimento acima de $180^{\circ} \mathrm{C}$ (KLOCK, 2010).

Cerca de $90 \%$ dos extrativos da madeira são removidos durante a fase de extração de cozimento. Ácidos graxos e resinosos formam sais de sódio e são removidos posteriormente do licor negro como "tall oil"(sabão), óleo de pinheiro. Voláteis como a terebentina podem ser recuperadas dos vapores de alívio durante a vaporização e cozimento (KLOCK, 2010). 


\section{MATERIAIS E MÉTODOS}

\subsection{Materiais}

Para realização deste trabalho foram utilizados cavacos obtidos industrialmente de touceiras de Bambusa vulgaris Schrad. ex J.C. Wendl. com 2 anos de idade das plantações da empresa Itapagé S/A, na fazenda Cajulândia, situada na cidade de Coelho Neto, estado do Maranhão, região leste, posicionado à latitude $04^{\circ} 15^{\prime} 25^{\prime \prime} \mathrm{S}$ e longitude $43^{\circ} 00^{\prime} 46^{\prime \prime} \mathrm{O}$ (Figura 1). Esta região apresenta temperaturas médias de $28^{\circ} \mathrm{C}$ e um clima tropical semi-árido com 1000 mm de precipitação e 1500mm de evapo-transpiração anual. Encontra-se segundo o Sistema Brasileiro de Classificação de Solos no tipo latossolo vermelho amarelo $(94,06 \%)$ e laterita hidromórfica $(5,94 \%)$.

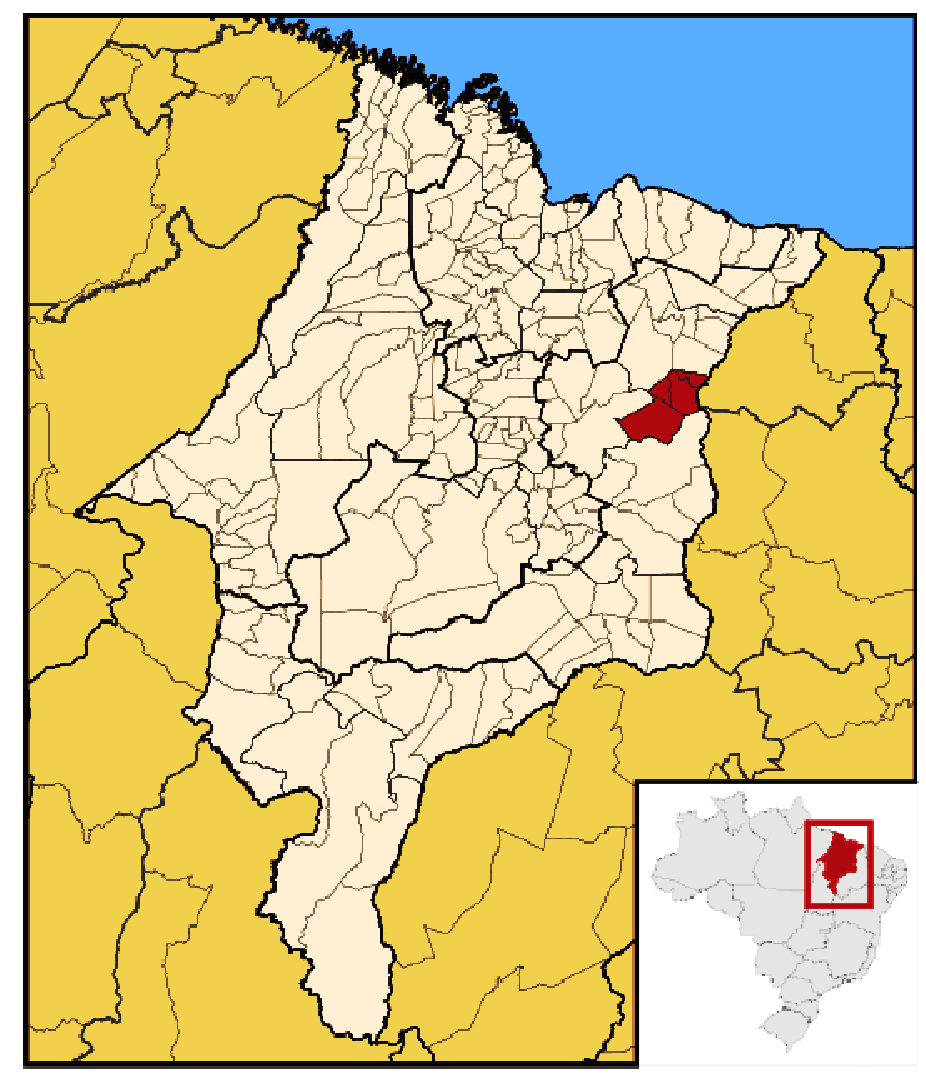

Figura 1: Localização do município de Coelho Neto/MA - Brasil.

\subsection{Métodos}

A pesquisa se realizou na Universidade de Brasília no departamento de Engenharia Florestal, em Brasília - DF. E no Laboratório de Química, Celulose e Energia "Luiz Ernesto George Barrichelo" (LQCE-LEGB) do Departamento de 
Ciências Florestais da Escola Superior de Agricultura Luiz de Queiroz - USP/ESALQ, em Piracicaba - SP.

\subsubsection{Classificação dos cavacos}

Inicialmente os cavacos foram submetidos a um processo de classificação manual para retirada de impurezas (cascas, lascas e cavacos defeituosos). Posteriormente os cavacos foram submetidos a um processo de tamisação em um conjunto de peneiras dotado de movimento vibratório para remoção de finos, cascas e cavacos de grandes dimensões (over-size) (Figura 2). Foram selecionados os cavacos com espessura entre 4 e $6 \mathrm{~mm}$. Os cavacos classificados foram homogeneizados, secos ao ar, armazenados em sacos de polietileno e mantidos sob refrigeração para serem conservados para análises posteriores.

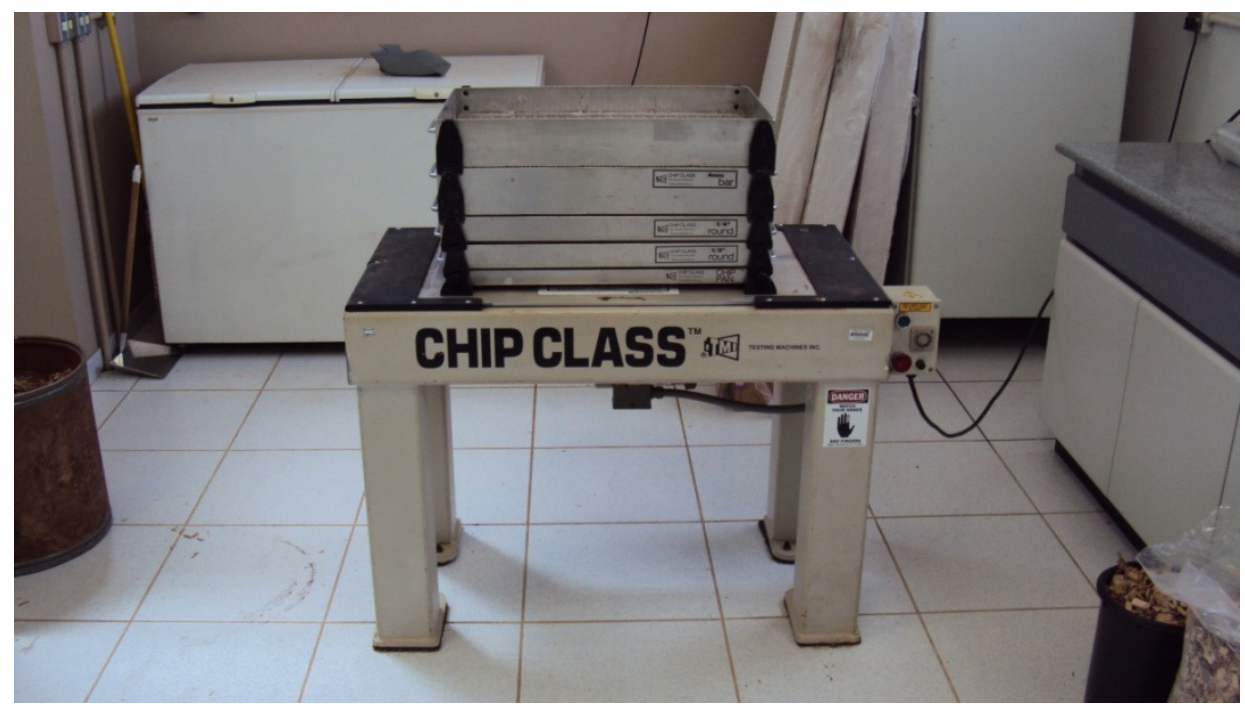

Figura 2: Classificador elétrico com peneiras vibratórias no LQCE.

\subsubsection{Dimensões dos cavacos}

Para determinação das dimensões dos cavacos (comprimento, largura e espessura) foram preparadas 3 amostras com $250 \mathrm{~g}$. Os cavacos foram medidos com paquímetro e separados em classes, com amplitude de $1 \mathrm{~mm}$ para comprimento e largura; e 0,5 $\mathrm{mm}$ para espessura.

Os cavacos, depois de medidos e classificados, foram colocados em estufa a $105 \pm$ $3^{\circ} \mathrm{C}$ até atingirem peso constante. Com base no peso seco total e no peso seco de cada 
classe, foi determinada a porcentagem em peso de cada classe de cavacos nas amostras analisadas.

Os resultados destas análises serão apresentados em gráficos de distribuição de freqüência relativa e absoluta.

\subsubsection{Densidade básica}

A densidade básica dos cavacos foi determinada através do método do máximo teor de umidade (BRASIL et al, 1972), tomando-se 3 amostras de aproximadamente $20 \mathrm{~g}$ de cavacos cada.

Cada amostra devidamente identificada, foi imersa em água destilada. Para acelerar a adsorção e absorção da água utilizou-se vácuo (125 mm $\mathrm{Hg}$ ) intermitentemente durante cinco dias. Em seguida as amostras foram mantidas em água até saturação completa o que foi constatado por pesagens sucessivas.

A densidade básica $(d b)$ é dada pela seguinte equação (2):

$$
d b=\frac{1}{\frac{P m-P a s}{P a s}+\frac{1}{G s}}
$$

Em que:

Pm = peso do ar dos cavacos saturados após a remoção, com papel absorvente, da água superficial Pas = peso absolutamente seco dos cavacos, conseguido através da secagem em estufa a $105 \pm 3 \mathrm{oC}$ até peso constante Gs $=$ densidade da substância madeira $\left(1,53 \mathrm{~g} / \mathrm{cm}^{3}\right)$

Os resultados são apresentados como sendo a média aritmética das 3 amostras.

\subsubsection{Caracterização anatômica da madeira}

Para determinação das dimensões das fibras foram retiradas com uso de estilete pequenas lascas de vários cavacos até integralizar aproximadamente $50 \mathrm{~g}$. Este material foi submetido à maceração com peróxido de hidrogênio e ácido acético $1: 1$ a $60{ }^{\circ} \mathrm{C}$ por 
um período suficiente para que ocorresse a individualização dos elementos anatômicos. Após a individualização do material, o mesmo foi lavado com água destilada. Com o material dissociado foram montadas 10 lâminas histológicas e de cada lâmina foram medidos comprimento, largura, diâmetro do lume e espessura de parede de 10 fibras, totalizando 100 medições.

Com os valores médios das dimensões das fibras foram calculadas as seguintes relações com as equações a seguir: fração de parede (FP) eq. (3), coeficiente de flexibilidade (CF) eq. (4), índice de Runkel (IR) eq. (5) e índice de enfeltramento (IF) eq. (6):

$$
\begin{gathered}
\mathrm{FP}=\frac{2 * \mathrm{E}}{\mathrm{L}} * 100 \\
\mathrm{CF}=\frac{\mathrm{DL}}{\mathrm{L}} * 100 \\
\mathrm{IR}=\frac{2 * \mathrm{E}}{\mathrm{DL}} \\
\mathrm{IF}=\frac{\mathrm{C}}{\mathrm{L}}
\end{gathered}
$$

Em que:

$\mathrm{C}=$ comprimento da Fibra;

$\mathrm{E}=$ espessura da parede da fibra;

$\mathrm{L}=$ largura da fibra;

DL = diâmetro do lume da fibra.

\subsubsection{Composição química da madeira}

Amostras de cavacos classificados de B. vulgaris foram reduzidas à serragem em moinho laboratorial e classificada em peneiras de 40-60 mesh para obtenção dos teores 
de extrativos, lignina e holocelulose segundo a metodologia utilizada no LQCE-LEGB ESALQ - USP (Apêndice A); as análises foram realizadas em duplicatas.

\subsubsection{Processo de polpação}

Para definição das condições de polpação kraft visando a obtenção das polpas com os níveis de deslignificação definidos, foi realizada inicialmente uma curva de cozimento com diferentes cargas de álcali, utilizando-se digestor rotativo aquecido eletronicamente trifásico RegMed, dotado de 8 cápsulas individualizadas com capacidade de $450 \mathrm{ml}$ cada, possibilitando a execução de todas as amostras com diferentes níveis de álcali ativo de uma só vez (Figura 3). Foram feitas três repetições para cada carga de álcali totalizando três cozimentos. Na tabela 1 são apresentadas as condições de cozimento e os dados dos cozimentos se encontram no apêndice B.

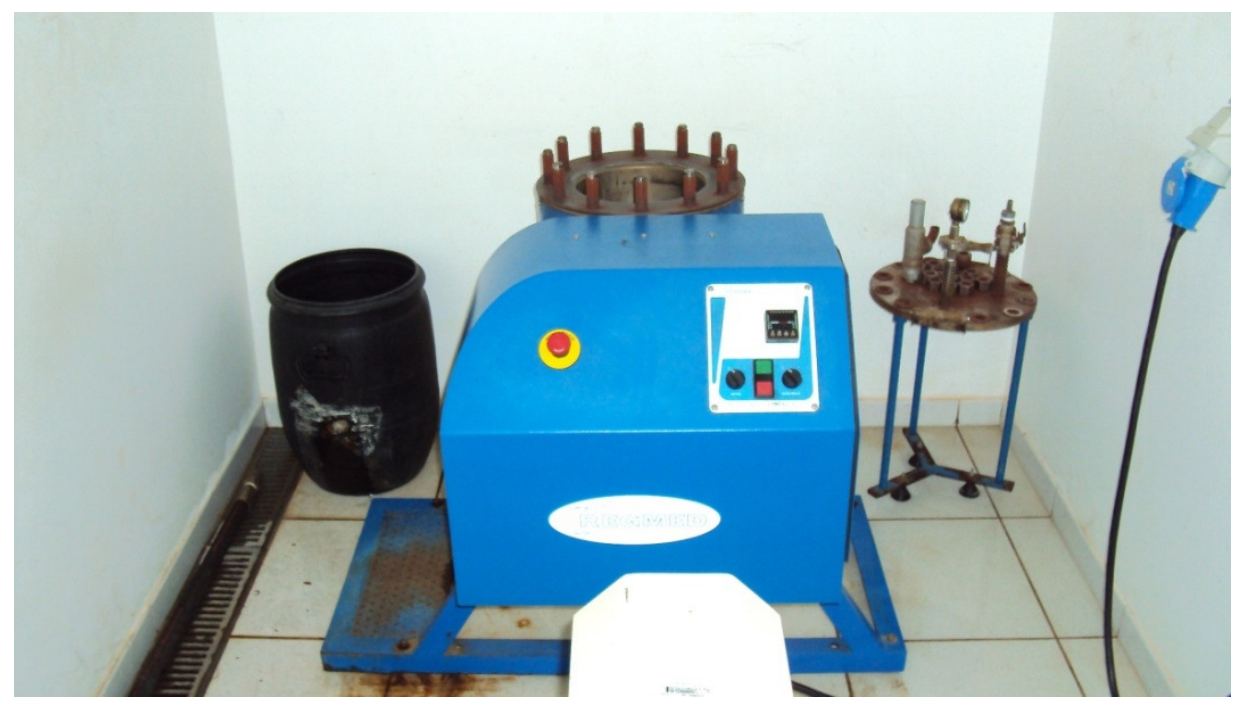

Figura 3: Digestor rotativo aquecido eletronicamente RegMed no LQCE

Tabela 1: Condições para curva de cozimento do processo de polpação Kraft.

Parâmetro

Álcali ativo, \% como NAOH

Madeira, $g$

Sulfidez, \%

Relação licor : Madeira, L:K

Tempo de aquecimento, min

Tempo de cozimento, min

Temperatura Máx., ${ }^{\circ} \mathrm{C}$

\section{Condições}

70

25

$4: 1$

90

60

170 


\subsubsection{Análise do licor negro}

Ao final de cada cozimento o lícor negro foi coletado para análises. Os licores obtidos foram analisados em duplicata, de acordo com os parâmetros descritos na tabela 2 e suas respectivas normas.

Tabela 2: Parâmetros determinados nos licores negros resultantes do processo Kraft.

\begin{tabular}{cc}
\hline Parâmetros & Norma \\
\hline Álcali ativo residual $(\mathrm{g} / \mathrm{l})$ & TAPPI T625 cm-85 \\
Teor de sólidos $(\mathrm{g} / \mathrm{l})$ & TAPPI T625 cm-85 \\
$\mathrm{pH}$ do lícor negro & TAPPI T625 wd-99 \\
Liginina residual $(\mathrm{g} / \mathrm{l})$ & Metodologia descrita no apêndice C \\
\hline
\end{tabular}

\subsubsection{Análise da polpa}

Ao final de cada cozimento as polpas foram lavadas em água corrente até perder todo o licor residual, depuradas em depurador laboratorial com fendas de 0,5mm, centrifugadas, desagregadas e armazenadas em sacos de polietileno e mantidas sob refrigeração para análises posteriores; os rejeitos foram coletados e secos em estufa $105 \pm 3{ }^{\circ} \mathrm{C}$ até peso constante.

As polpas obtidas foram analisadas de acordo com os parâmetros descritos na tabela 3 .

Tabela 3: Parâmetros determinados nas polpas celulósicas do processo Kraft.

\begin{tabular}{cc}
\hline Parâmetros & Normas \\
\cline { 3 - 3 } Rendimento bruto, $\%$ & $\begin{array}{r}\text { Relação entre peso absolutamente seco (a. s.) de celulose e } \\
\text { peso a.s. da madeira. }\end{array}$ \\
Relação entre peso a. s. de celulose depurada e o peso a. s. \\
da madeira.
\end{tabular}

Nota: Sinal convencional utilizado:

*parâmetro determinado nas polpas celulósicas com número kappa abaixo de $30 \pm 2$.

** Centi Poise $(1 \mathrm{cP}=1 \mathrm{mPa} . \mathrm{s})$ 


\subsubsection{Análise estatística}

Para os resultados da análise do licor negro e polpa foram calculados os valores médios, desvio padrão e coeficiente de variação. E para comparar as médias foi feito análise de variância seguida do teste de Tukey, ao nível de significância a 5\%, para detectar quais são as médias estatisticamente diferentes das demais (VIEIRA, 1980). A análise estatística foi feita com o auxílio do software BioStat 2009. 


\section{RESULTADOS E DISCUSSÕES}

\subsection{Caracterização da matéria-prima}

Nos processos de polpação tanto as características da matéria-prima como as características do processo vão exercer influência sobre as propriedades do produto final. No que diz respeito ao material utilizado, Vasconcelos (2005) dividiu, quanto as suas propriedades intrínsecas e as suas características adquiridas devido ao processo.

As características intrínsecas são aquelas relacionadas à qualidade da madeira tais como densidade básica, composição química (teor de extrativos, lignina e holocelulose) e dimensões dos traqueídes (comprimento e largura dos traqueídes, espessura da parede celular e diâmetro do lume).

As características do material relacionadas ao processamento industrial (preparação da madeira para o processo de polpação) dependem, além das características intrínsecas do material, da tecnologia e das condições operacionais empregadas. Entre as características do material relacionadas ao processo, merecem destaque as dimensões dos cavacos (comprimento, largura e espessura), pois estes influenciam de forma determinante o desempenho da madeira frente ao processo de polpação kraft.

\subsubsection{Classificação dos cavacos}

Os cavacos foram classificados em função de sua espessura e largura, em um conjunto de peneiras classificatórias visando à determinação em peso em cada classe de cavacos na amostra. Os resultados são apresentados nas figuras 3 e 4. 


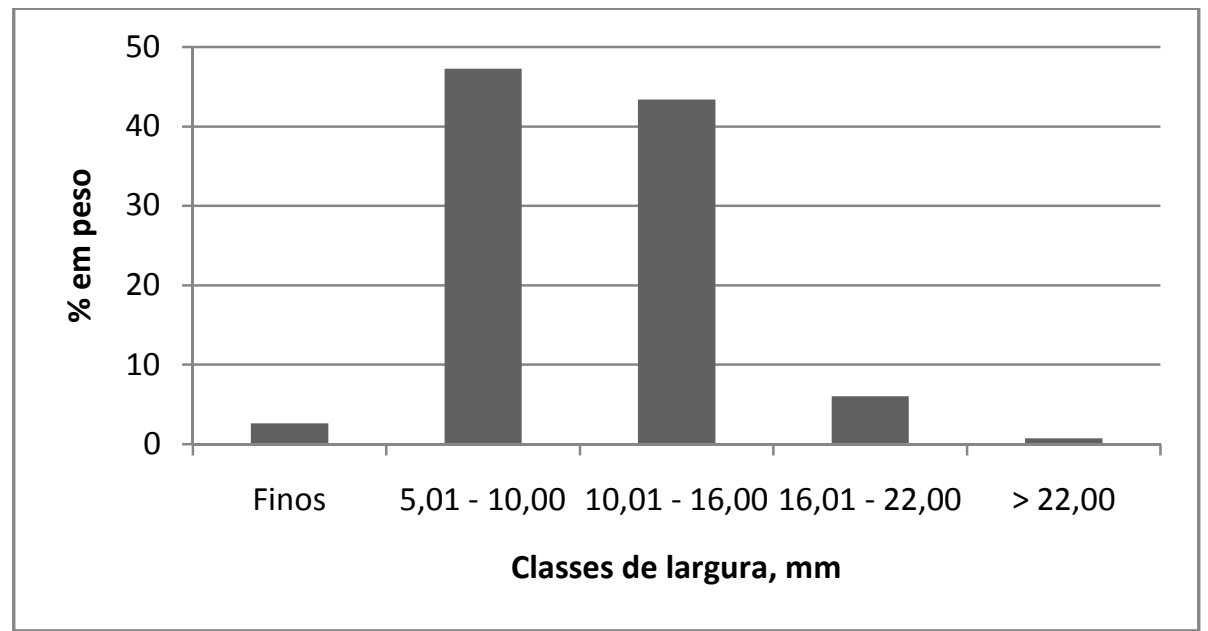

Figura 4: Classificação dos cavacos em classes de largura média.

Os resultados apresentados na figura 3 mostram que os cavacos de B. vulgaris utilizados neste trabalho apresentam largura de 5,01 a 10,00mm, sendo pequena a proporção de finos e cavacos pequenos. A quantidade reduzida de cavacos pequenos e finos é um fator que pode ser considerado benéfico na operação do digestor em escala industrial, pois facilita a extração e circulação de licores através das peneiras de extração localizadas em suas paredes (VASCONCELOS, 2005).

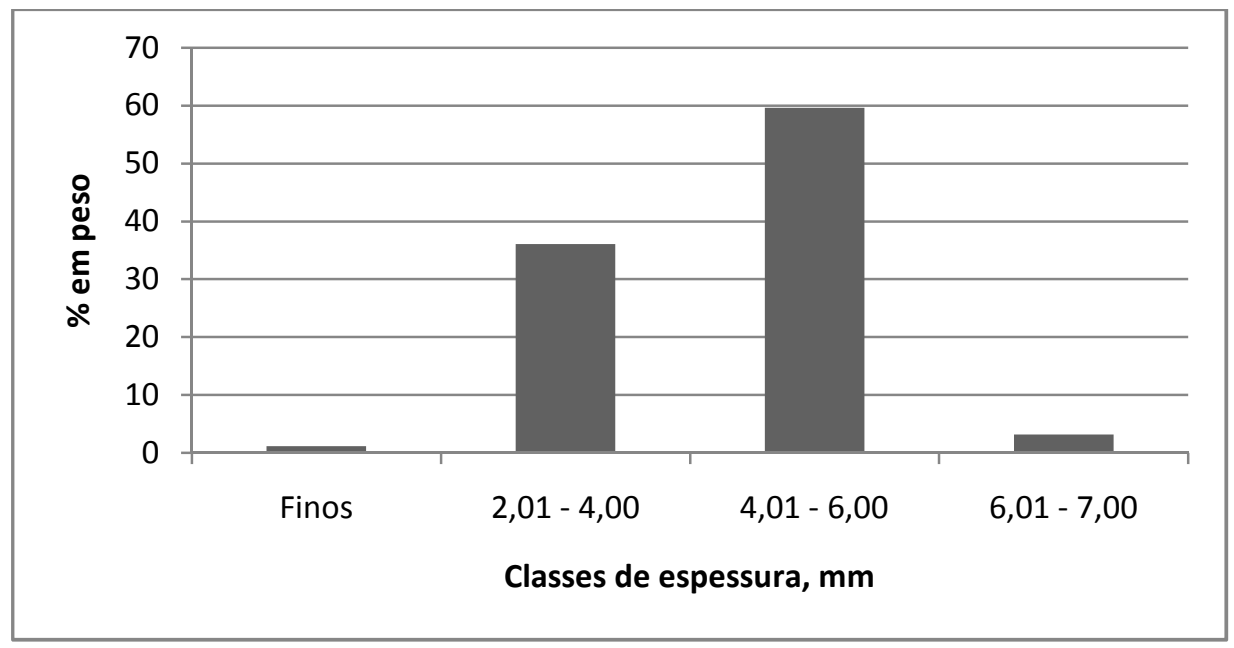

Figura 5: Classificação dos cavacos em classes de espessura média.

Os resultados mostrados na figura 5 mostram que a maior parte dos cavacos utilizados neste trabalho tem espessura entre 4,01 e 6,00 mm (59,0\%), contudo, também se tem uma proporção considerável na classe de 2,01 a 4,00 mm (36,0\%). 


\subsubsection{Dimensões dos cavacos}

As dimensões dos cavacos são de fundamental importância para que ocorra uma distribuição homogênea e impregnação efetiva dos agentes químicos de cozimento para o interior da madeira (WEHR \& BARRICHELO, 1993).

Vários estudos têm procurado estabelecer as melhores dimensões de cavacos, para que se assegure uma distribuição rápida e efetiva do licor de cozimento na madeira, resultando em uma alta qualidade da celulose produzida.

Visto a importância das dimensões dos cavacos no desempenho global do processo de polpação foram determinados o comprimento, largura e espessura dos cavacos utilizados neste trabalho e com os resultados obtidos foi calculado, para cada uma destas dimensões, a média, desvio padrão, coeficiente de variação e limites inferiores e superiores que estão apresentados na tabela 4.

Tabela 4: Dimensões dos cavacos.

\begin{tabular}{cccccc}
\hline Dimensão & $\begin{array}{c}\text { Média } \\
(\mathbf{m m})\end{array}$ & $\begin{array}{c}\text { Desvio Padrão } \\
(\mathbf{m m})\end{array}$ & $\begin{array}{c}\text { Coeficiente de Variação } \\
(\%)\end{array}$ & $\begin{array}{c}\text { Máximo } \\
(\mathbf{m m})\end{array}$ & $\begin{array}{c}\text { Mínimo } \\
(\mathbf{m m})\end{array}$ \\
\hline Comprimento & 22,83 & 7,88 & 34,50 & 71,21 & 4,11 \\
Largura & 9,18 & 3,49 & 38,06 & 25,50 & 2,76 \\
Espessura & 4,01 & 0,89 & 22,22 & 6,96 & 1,04 \\
\hline
\end{tabular}

Broderick et al (1996) afrimam que cavacos de alta qualidade têm em média, espessura entre 2 a $5 \mathrm{~mm}$ e comprimento entre 10 e $30 \mathrm{~mm}$.

Já Andrade et al. (1978), estudando apenas o efeito da espessura dos cavacos, encontrou que o valor de 4 a $6 \mathrm{~mm}$ é que proporcionou os melhores resultados. Contudo, estes mesmos autores reconhecem que está faixa é bastante restrita e muito difícil de se alcançar industrialmente, assim, completam que é perfeitamente possível se trabalhar com uma amplitude um pouco maior, de 2 a $8 \mathrm{~mm}$, também se obtendo bons resultados.

O valor médio da espessura dos cavacos foi de 4,01 mm (Tabela 4), podendo ser considerado como um bom valor, com base no que foi discutido acima. Em relação ao comprimento dos cavacos, o valor encontrado - 22,83mm - se encontra dentro do intervalo sugerido por Broderick (1996). 
Estes resultados, de uma forma geral, podem ser considerados como adequados para produção de celulose. Nas figuras 6, 7 e 8 são apresentadas as distribuições das dimensões dos cavacos, que permitem uma melhor visualização acerca da uniformidade dos cavacos.

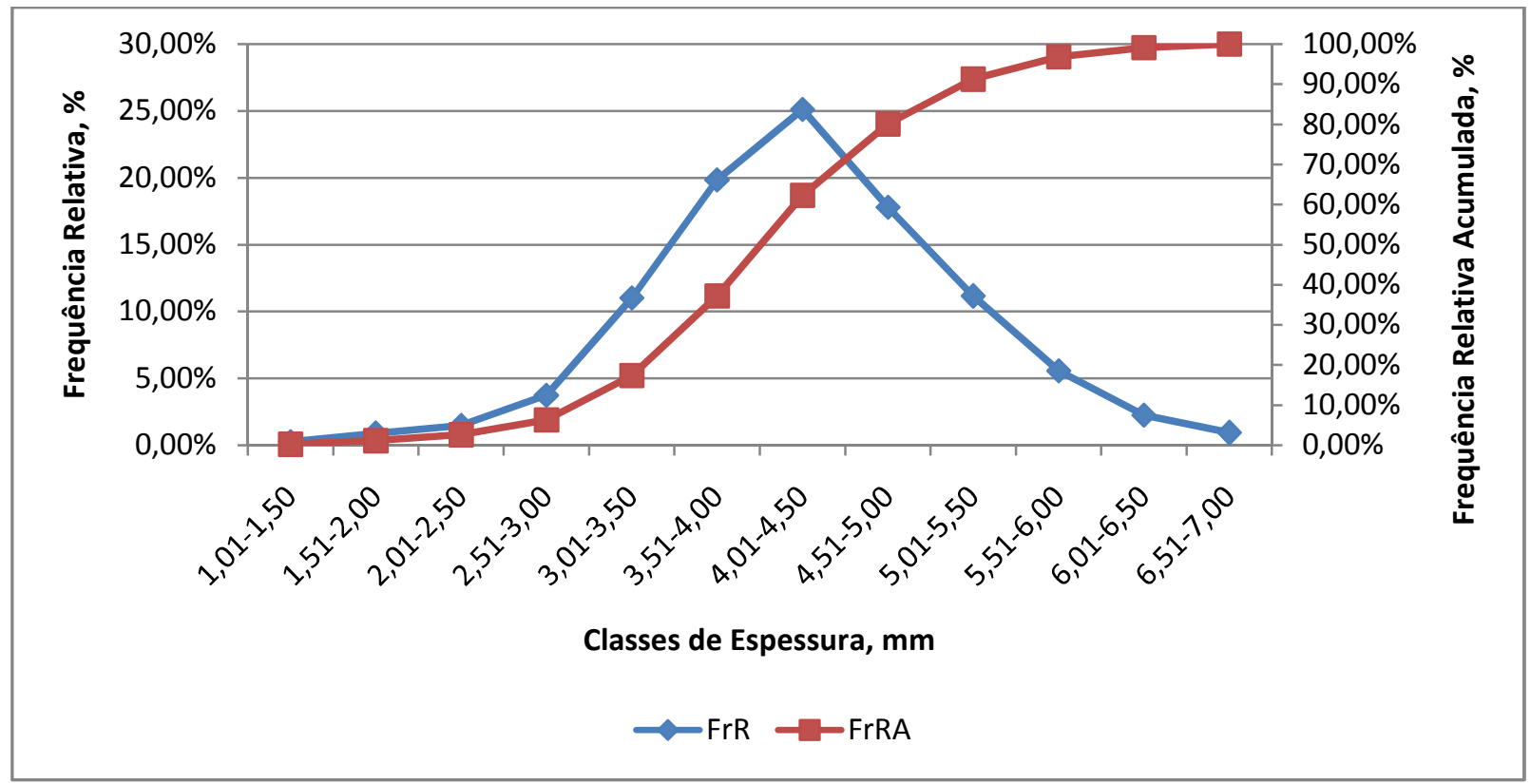

Figura 6: Distribuição de cavacos por classes de espessura.

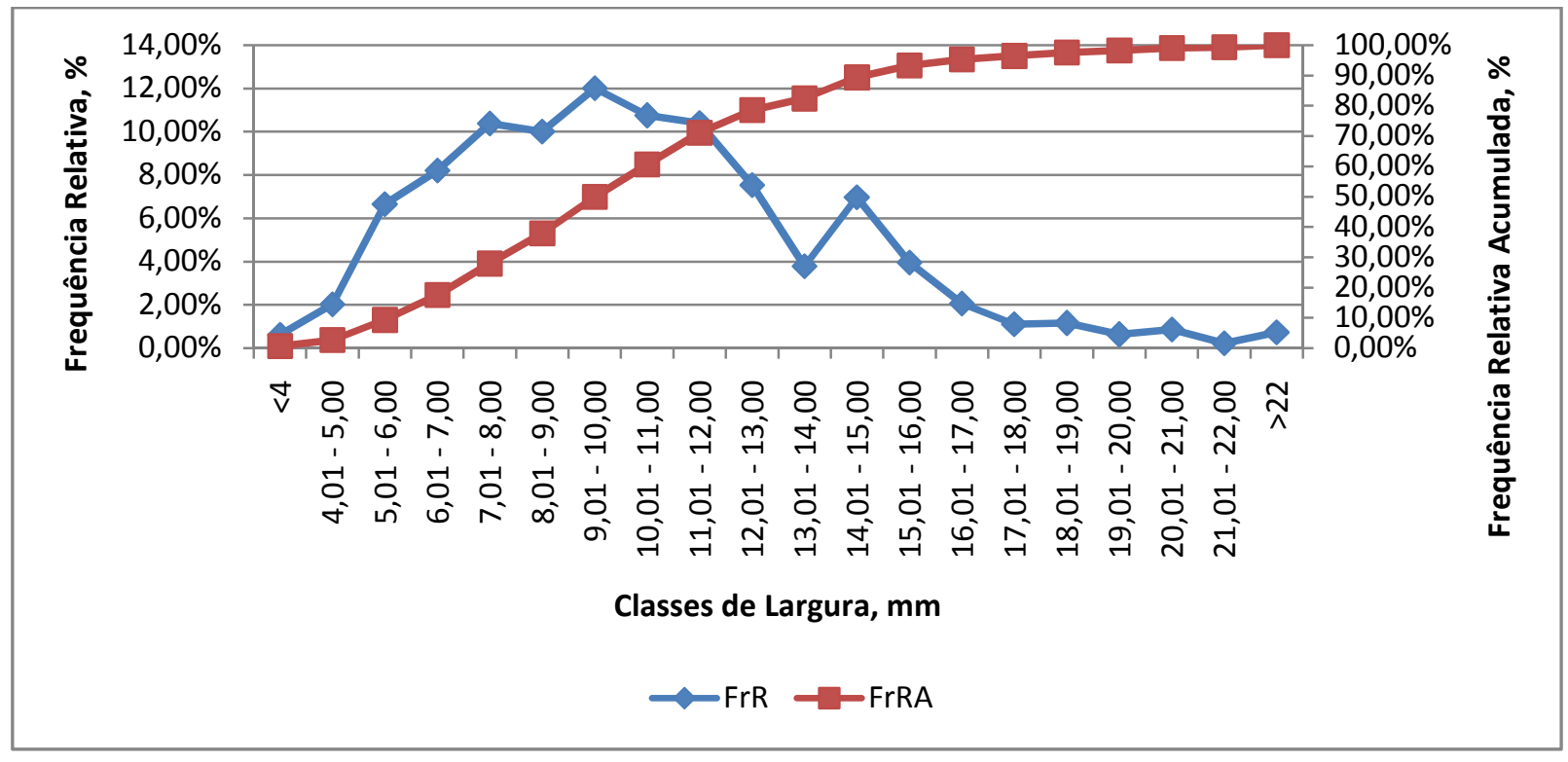

Figura 7: Distribuição de cavacos por classes de largura. 


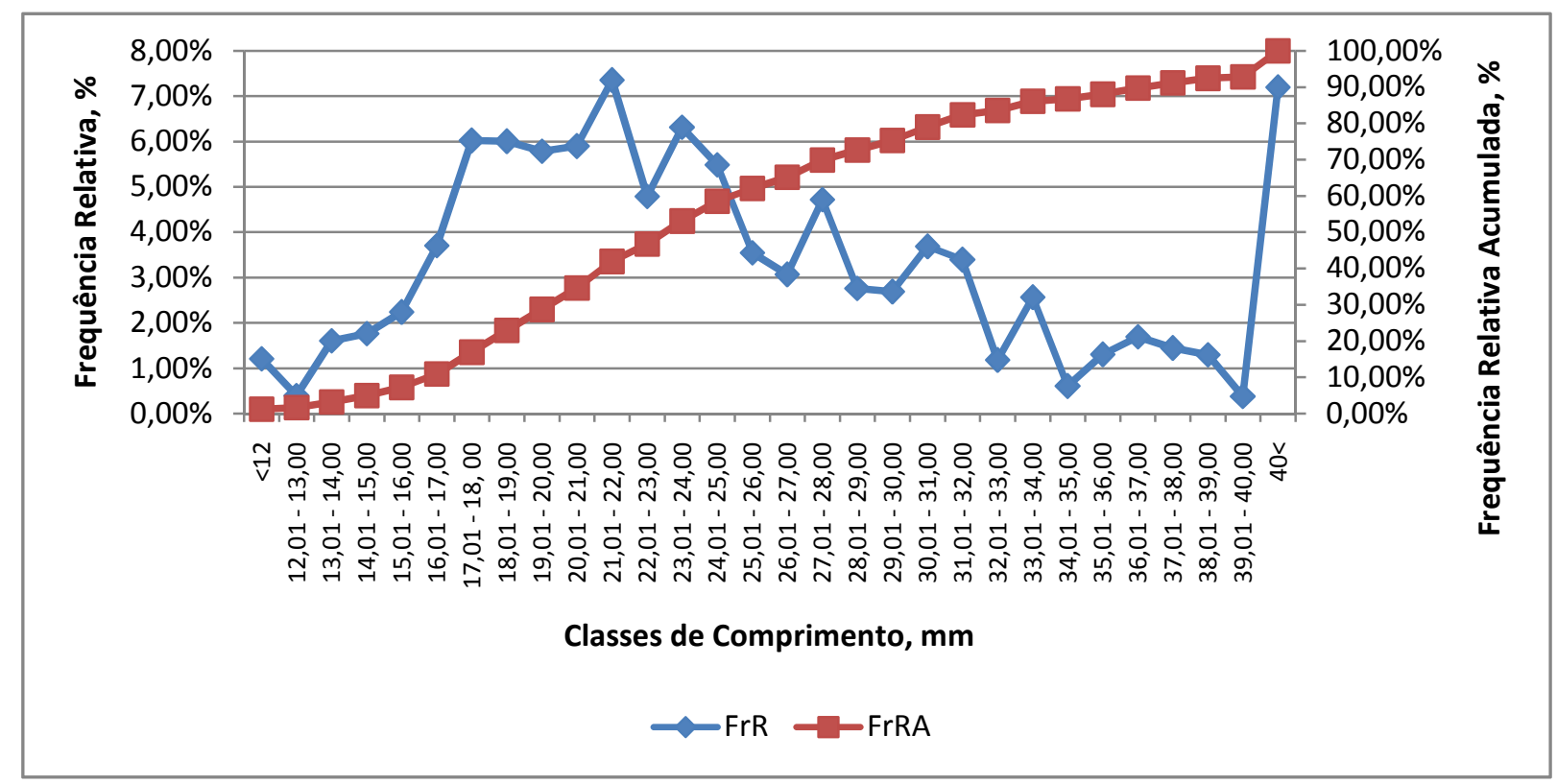

Figura 8: Distribuição dos cavacos por classes de comprimento.

Gullichsen et al. (1992) diz que uma grande quantidade de trabalhos já demonstrou que na etapa de impregnação a dimensão, o mais importante é a espessura dos cavacos, uma vez que influencia nível de deslignificação, teor de rejeitos e resistências da polpa. Desta forma, entre as figuras apresentadas anteriormente, a figura 6 é a que merece maior destaque, visto que nela é abordada a espessura dos cavacos.

Assim, analisando-se a distribuição das classes de espessura (Figura 6), ou seja, a uniformidade dos cavacos, no caso os cavacos apresentam um modelo mono-modal, com picos nas classes de 4,01 - 4,50mm. A maior parte dos cavacos estão dentro daquela faixa estabelecida como ideal sugerido Andrade et al. (1978).

Já o comprimento e a largura de cavacos destinados a processos de polpação são de importância secundária quando comparados à espessura dos mesmos quando se consideram os aspectos de impregnação. Em termos de processo, cavacos compridos ou largos tendem a apresentar dificuldades de manipulação e transporte além de dificultar o aproveitamento volumétrico dos digestores.

Os resultados da tabela 4 e da figura 7 mostram que os cavacos apresentam uma largura média de 9,18 mm, grande amplitude de valores e distribuição heterogênea. A distribuição em classes de largura não apresenta um modelo típico o que pode indicar que este parâmetro não está sob controle e que sofre influência de diversos outros fatores que também não estão sob controle tais como diâmetro e comprimento dos 
colmos, densidade básica da madeira, teor de umidade entre outros. Estes resultados, no entanto, tem pouca influência sobre o processo de polpação kraft.

Com relação ao comprimento dos cavacos Vasconcelos (2005) observa-se que este deve ser maximizado, obviamente, considerando-se os aspectos industriais envolvidos, tanto em termos de produção, como de manipulação e ocupação volumétricas de silos e digestores. Considerando-se que o comprimento do cavaco considera o plano longitudinal da madeira, no processo de produção de cavacos há efetivamente o corte de fibras; quanto mais curtos os cavacos, maior a incidência de fibras cortadas, fato este que, em casos extremos, contribuíra para a perda de qualidade da polpa celulósica em função da presença de elevada quantidade de fibras com menor comprimento.

Os resultados apresentados na figura 8 e na tabela 4 também mostram que os cavacos de B. vulgaris utilizados neste trabalho apresentam comprimento de 22,83mm, valor este que está bastante próximo daqueles compreendidos na categoria de cavacos de alta qualidade segundo (SMOOK, 1982 apud BRODERICK et al, 1996). O desviopadrão e a amplitude de distribuição são altos, sendo que aproximadamente $55 \%$ dos cavacos encontram-se compreendidos entre 17 e $26 \mathrm{~mm}$ de comprimento.

Os resultados para dimensões de cavacos mostram que o método utilizado nesta fase gera resultados importantes devido ao seu maior nível de detalhamento em comparação com aqueles obtidos na classificação de cavacos (item 2.4.1.1), revelando características dos cavacos não identificadas anteriormente e que são de extrema importância na análise dos resultados sobre as características do material, bem como da sua possível influência sobre o processo de polpação.

Os resultados mostram que os cavacos apresentam baixa uniformidade, contudo suas dimensões, em especial a espessura, se encontram em uma boa faixa de valores, o que não deve trazer grandes implicações ao processo de polpação.

\subsubsection{Densidade básica dos cavacos}

A densidade básica é um dos parâmetros mais importantes para a determinação da qualidade da madeira para produção de polpa celulósica por ser de fácil determinação e por estar diretamente relacionada às principais características do produto 
final (FOELKEL et al., 1992). Com isso, este parâmetro tem se constituído em um índice universal para avaliar a qualidade da madeira, que, de qualquer forma, deve ser analisado com critério para não se cometer erros nem exageros (FOELKEL et al., 1992; SILVA Jr, 1997).

Os cavacos de B. vulgaris nesse trabalho apresentaram densidade básica média de $0,494 \mathrm{~g} / \mathrm{cm}^{3}$. Os resultados encontrados nesse trabalho são semelhantes aos encontrados por Azzini et al. (1987), que analizando materiais provenientes da cidade de Tatuí - SP encontraram uma amplitude de resultados de 0,487 e 0,619 g/ $\mathrm{cm}^{3}$. A densidade básica da espécie estudada favorece a penetração e distribução do licor durante o cozimento.

\subsubsection{Caracterização anatômica da madeira}

A partir das dimensões morfológicas das fibras, foram estabelecidas algumas relações, procurando-se correlacioná-las com as resistências e demais características da polpa celulósica. As principais relações, segundo Mogollón e Aguilera, (2002) são: índice de enfeltramento, coeficiente de flexibilidade, fração parede, e índice de Runkel.

Na tabela 5 estão apresentadas as dimensões e relações morfológicas das fibras dos cavacos de $B$. vulgaris utilizados neste trabalho.

Tabela 5: Resultado das dimenções e relações morfológicas das fibras de B. vulgaris.

\begin{tabular}{cccc}
\hline Dimenção e Relação & Média & Desvio Padrão & Coeficiente de Variação, \% \\
\hline Comprimento, mm & 2,58 & 0,68 & 26,36 \\
Largua, $\mu \mathrm{m}$ & 20,13 & 4,38 & 21,76 \\
Diâmetro do lume, $\mu \mathrm{m}$ & 10,29 & 5,12 & 49,76 \\
Espessura da parede, $\mu \mathrm{m}$ & 5,30 & 3,57 & 67,20 \\
Fração parede, $\%$ & 52,73 & - & - \\
Coeficiente de flexibilidade, $\%$ & 51,12 & - & - \\
Índice de Enfeltramento & 128,97 & - & - \\
Índice de Runkel & 1,03 & - &
\end{tabular}

Nota: Sinal convencional utilizado:

- Não de aplica ao dado numérico.

As dimensões das fibras encontradas por Castro e Silva (2010) para B. vulgaris com 2 anos foram semelhantes as do material em estudo, sendo os valores obtidos $3,43 \mathrm{~mm}$ para comprimento, $15,41 \mu \mathrm{m}$ para largura, $3,73 \mu \mathrm{m}$ para diâmetro lume e $5,84 \mu \mathrm{m}$ para espessura de parede. O comprimento foi superior ao encontrado neste 
trabalho, mas cabe ressaltar que esta característica melhora o enfeltramento das fibras, que por sua vez está relacionado à resistência a tração da polpa celulósica e papel.

O índice de Runkel, o qual avalia o grau de colapso das fibras durante o processo de produção de papel. Quanto menor for o índice, maior será o grau de colapso, permitindo às fibras uma maior superfície de contato, com isso estabelecendo um maior número de ligações entre eles, o que resulta em um papel com maior resistência à tração e ao estouro, ou seja, aquelas resistências que dependem de ligações entre as fibras são beneficiadas.

Na tabela 6 se tem a classificação proposta por Runkel (1952 apud PAULA \& ALVES, 1997).

Tabela 6: Classificação de Runkel

\begin{tabular}{ccc}
\hline Grupo & Índice de Runkel & Classificação \\
\hline I & $<0,25$ & Excelente para a fabricação de papel \\
II & $0,25-0,50$ & Muito boa para papel \\
III & $0,50-1,00$ & Boa para papel \\
IV & $1,00-2,00$ & Regular para papel \\
V & $>2,00$ & Inadequada para papel \\
\hline
\end{tabular}

Considerando-se a tabela 6, o valor do índice de Runkel obtido para o material em questão, que foi de 1,03, permite classificá-lo no grupo IV - material regular para a produção de papel.

A fração parede das fibras de B. vulgaris utilizadas neste trabalho, encontra-se dentro do padrão para produção de polpa celulósica de boa qualidade; de acordo com Mogollón e Aguilera (2002), para valores de fração parede superiores a $40 \%$ assume-se que as fibras apresentam boa flexibilidade. Segundo D'Almeida (1988) A um valor maior de fração parede, correspondem fibras mais rígidas e menos propensas à ligação entre si.

O coeficiente de flexibilidade, na prática tem o mesmo significado que o índice de Runkel, indica o grau de colapso (achatamento) que as fibras sofrem durante o processo de fabricação do papel, quanto maior seu valor, mais flexível será a fibra, ocorrendo maiores possibilidades de ligações entre as mesmas, o que tende a aumentar as resistências à tração e ao estouro (D'ALMEIDA, 1988; SHIMOYAMA \& WIECHETECK, 1993; PAULA \& ALVES, 1997). 
Para o índice de enfeltramento, quanto maior o seu valor, maior resistência ao rasgo terá o papel (Moreschi, 1975; Mogollón e Aguilera, 2002), sendo assim muito bom o valor encontrado para $B$. vulgaris já que confere uma excelente flexibilidade e boa resistência ao papel produzido. Para todas as dimensões das fibras encontradas observou-se elevados coeficientes de variação e isso se deve a variação anatômica que ocorre no lenho de B. vulgaris, Fernandéz (2010) em estudo com mesma espécie também encontrou elevados coeficientes de variação.

\subsubsection{Composição química da madeira}

Considera-se fundamental a avaliação dos principais componentes químicos da madeira, pois estes exercem grande influência sobre os processos químicos de polpação, interferindo na qualidade do produto final e são considerados fatores limitantes para determinadas utilizações da madeira (ANDRADE, 2006).

Os extrativos e a lignina são constituintes considerados como indesejáveis no processo de produção de celulose química, sendo suas determinações, indicativos que podem propiciar indiretamente estimativas sobre rendimento de processo e consumo de reagentes durante a polpação. Na tabela 7 encontram-se as proporções da caracterização química.

Tabela 7: Resultados da comparação química da madeira de B. vulgaris.

\begin{tabular}{cc}
\hline Componente & Média, \% \\
\hline Holocelulose & 66,28 \\
Lignina total & 22,17 \\
Lignina insolúvel & 21,29 \\
Lignina solúvel & 0,88 \\
Extrativos totais & 11,55 \\
\hline
\end{tabular}

Os resultados de composição química do material em estudo encontram-se semelhantes aos de outros trabalhos que utilizaram a mesma espécie. Gomide et al (1982) encontrou para B. vulgaris teores de holocelulose, lignina e extrativos com valores de 64,94, 17,91 e 13,37\% respectivamente. Fernández (2010) em trabalho semelhante encontrou teores de holocelulose, lignina e extrativos com valores de 66,63, 22,91 e $9,46 \%$ respectivamente. 
Para P. taeda Goncalez (2002) encontrou teores de holocelulose, lignina e extrativos com valores de 64,50, 27,3 e 8,2\%. Pereira et al. (2000) encontrou, para Eucalyptus benthamii Maid. \& Camb. Teores de holocelulose, lignina e extrativos valores de $69,70 \%, 24,30 \%$ e $6,00 \%$. Os resultados supracitados se aproximam bastante aos resultados encontrados neste trabalho para B. vulgaris. 


\subsection{Análise do licor negro}

\subsubsection{Análise estatística}

$\mathrm{Na}$ tabela 8 encontra-se as médias aritiméticas (M), desvio padrão (S) e coeficientes de variação $(\mathrm{CV})$ da análise estatística do licor negro, nota-se que para o parâmetro álcali ativo residual (AAR) encontra-se valores de coeficiente de variação muito grandes.

Tabela 8: Análise estatística para os resultados dos parâmetros do licor negro.

\begin{tabular}{cccccccccc}
\hline & \multicolumn{10}{c}{ Álcali Ativo (\%), Base NaOH } \\
\hline & & 10 & 12 & 14 & 16 & 18 & 20 & 22 & 24 \\
\hline \multirow{4}{*}{ AAR (g/l) } & $\mathrm{M}$ & $0,00 \mathrm{a}$ & $0,00 \mathrm{a}$ & $1,81 \mathrm{a}$ & $4,69 \mathrm{~b}$ & $6,77 \mathrm{bc}$ & $8,70 \mathrm{~cd}$ & $10,38 \mathrm{~d}$ & $12,99 \mathrm{e}$ \\
& $\mathrm{S}$ & 0 & 0 & 0,93 & 1,05 & 1,65 & 0,52 & 0,66 & 0,67 \\
& $\mathrm{CV}(\%)$ & - & - & 51 & 22 & 24 & 6 & 6 & 5 \\
\hline \multirow{4}{*}{ pH resídual } & $\mathrm{M}$ & $9,49 \mathrm{a}$ & $10,15 \mathrm{~b}$ & $10,65 \mathrm{bc}$ & $11,19 \mathrm{~cd}$ & $11,69 \mathrm{~d}$ & $12,47 \mathrm{e}$ & $12,94 \mathrm{ef}$ & $13,20 \mathrm{f}$ \\
& $\mathrm{S}$ & 0,20 & 0,22 & 0,15 & 0,17 & 0,28 & 0,15 & 0,24 & 0,27 \\
& $\mathrm{CV}(\%)$ & 2 & 2 & 1 & 2 & 2 & 1 & 2 & 2 \\
\hline \multirow{2}{*}{ T. de Sólidos } & $\mathrm{M}$ & $9,20 \mathrm{a}$ & $10,84 \mathrm{~b}$ & $12,13 \mathrm{c}$ & $12,76 \mathrm{c}$ & $13,92 \mathrm{~d}$ & $14,05 \mathrm{de}$ & $14,70 \mathrm{de}$ & $14,88 \mathrm{e}$ \\
(g/l) & $\mathrm{S}$ & 0,90 & 0,17 & 0,01 & 0,15 & 0,06 & 0,03 & 0,14 & 0,04 \\
& $\mathrm{CV}(\%)$ & 10 & 2 & 0 & 1 & 0 & 0 & 1 & 0 \\
\hline \multirow{2}{*}{ Lig. Residual } & $\mathrm{M}$ & $17,08 \mathrm{a}$ & $25,52 \mathrm{~b}$ & $36,29 \mathrm{c}$ & $40,36 \mathrm{~cd}$ & $40,81 \mathrm{~cd}$ & $43,85 \mathrm{~cd}$ & $46,90 \mathrm{~d}$ & $47,61 \mathrm{~d}$ \\
(g/l) & $\mathrm{S}$ & 2,78 & 4,58 & 1,16 & 0,62 & 0,58 & 3,34 & 2,85 & 3,37 \\
& $\mathrm{CV}(\%)$ & 16 & 18 & 3 & 2 & 1 & 8 & 6 & 7 \\
\hline
\end{tabular}

Nota: * Os valores com letras iguais se igualam estatisticamente pelo teste de Tukey ao nível de significância a $5 \%$.

Sinal convencional utilizado:

- Não de aplica ao dado numérico.

$\mathrm{M}=$ Média

$\mathrm{S}=$ Desvio Padrão

$\mathrm{CV}=$ Coeficiente de Variação

\subsection{2. Álcali ativo resídual}

De acordo com Lombardo \& Padilha (1998) é importante que o álcali ativo no final do processo não caia a níveis tão baixos, podendo desta forma comprometer a qualidade da polpa através da reprecipitação da lignina, tendo-se como referência medias praticas entre 5 e $13 \mathrm{~g} / \mathrm{L}$.

De acordo com o autor supracitado faltou álcali ativo nos cozimentos de cargas de 10 a $16 \%$ e nos cozimentos de carga de 18 a $24 \%$ os resultados estão dentro das médias praticáveis.

A curva de álcali ativo residual em relação às cargas de álcali aplicadas está representada na figura 9. 


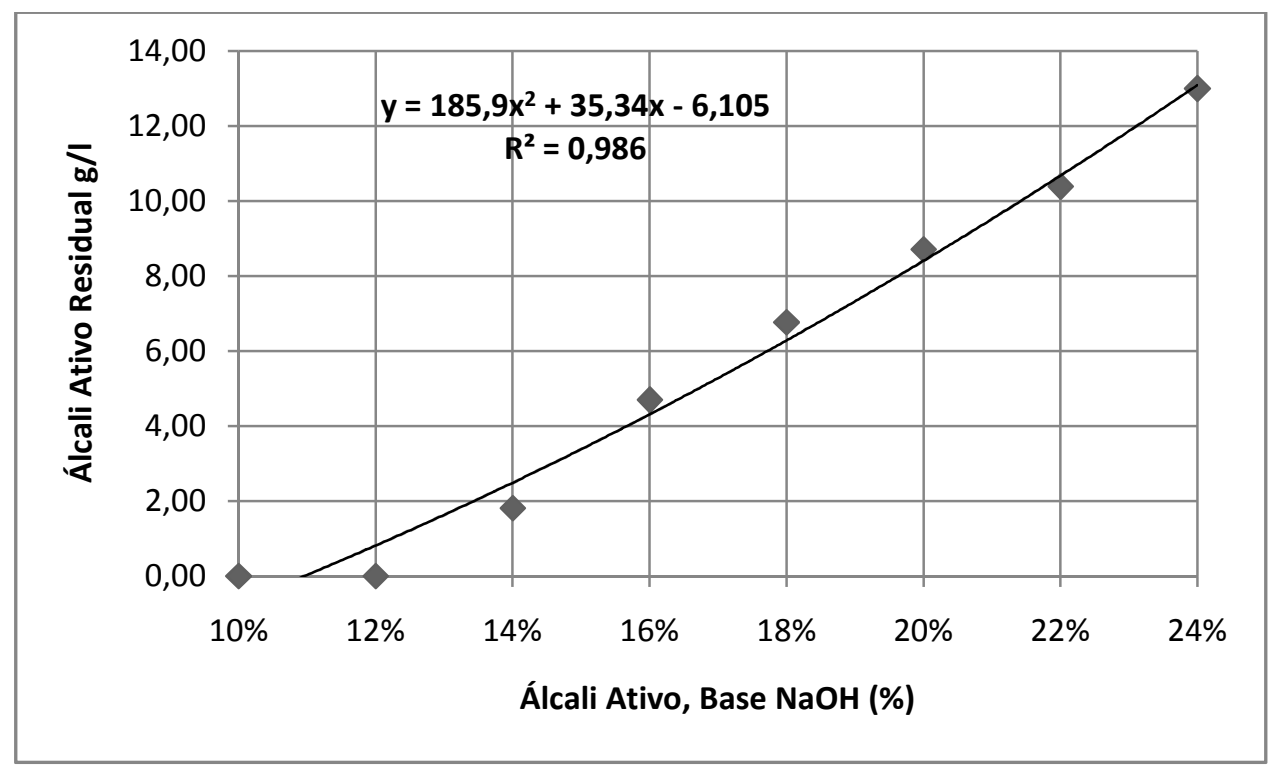

Figura 9: Álcali Ativo Residual (g/l) / Álcali Ativo, Base NaOH (\%).

\subsubsection{Teor de sólidos totais}

O teor de sólidos totais representa a fração de compostos inorgânicos presentes no licor inserido no cozimento, e também a fração de fragmentos orgânicos dissolvidos da madeira ao longo do processo (GOMES, 2009). Na figura 10 nota-se que o teor de sólidos totais aumenta junto com as cargas de álcali, conforme o esperado.

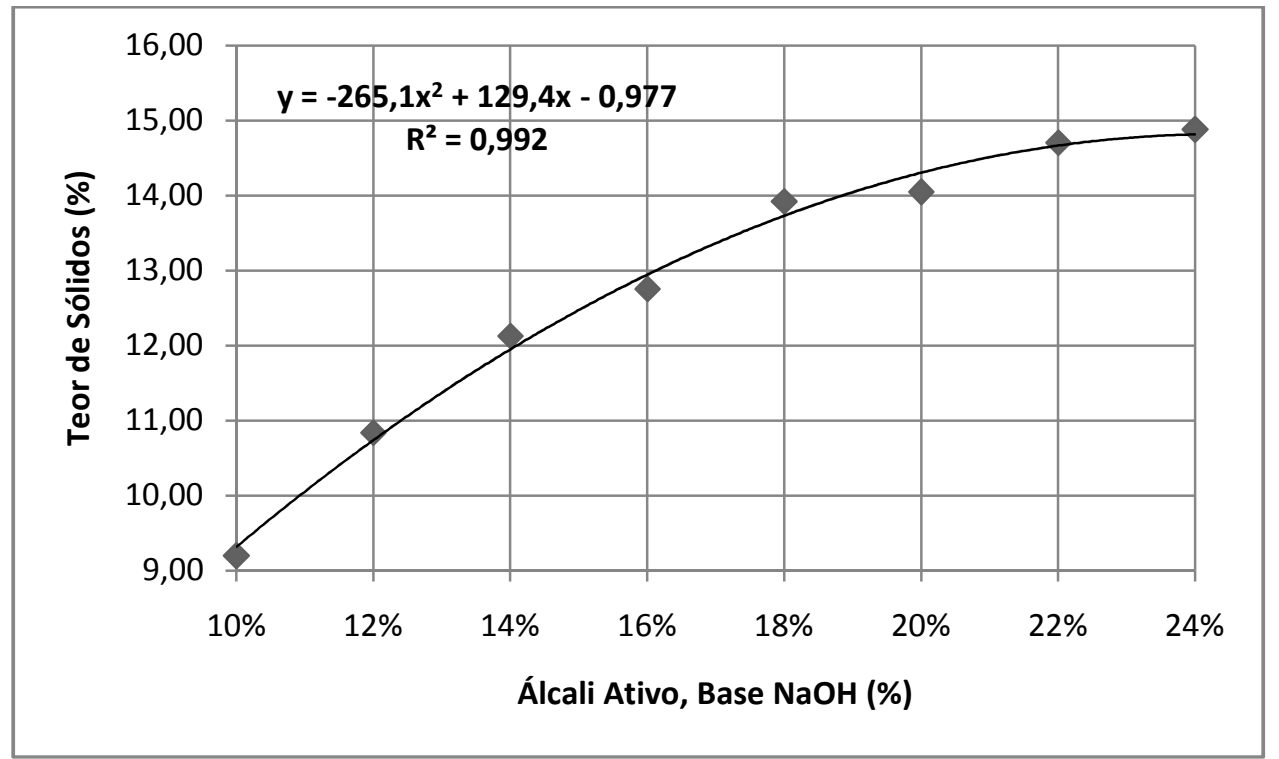

Figura 10: Teor de Sólidos (\%) / Álcali Ativo, Base $\mathrm{NaOH}(\%)$ 


\subsection{4. $\quad \mathrm{pH}$ do licor negro}

As reações químicas do processo de polpação Kraft ocorrem em meio alcalino, sendo injetada no início do cozimento uma solução extremamente básica. Conforme visualizado na figura $11, \mathrm{o} \mathrm{pH}$ do licor vai sofrendo redução conforme aumento das cargas de álcali. Santos (2005) ressalta que é extremamente importante que o pH do licor ao final do cozimento esteja superior a 11, pois isso indica presença de suficiente álcali residual, capaz de prevenir a precipitação de componentes orgânicos, inclusive a lignina, presentes no licor negro, o que prejudica a qualidade da polpa.

De acordo com o autor supracitado as cargas de 16 a $24 \%$ satisfazem as condições para prevenção da precipitação de componentes orgânicos.

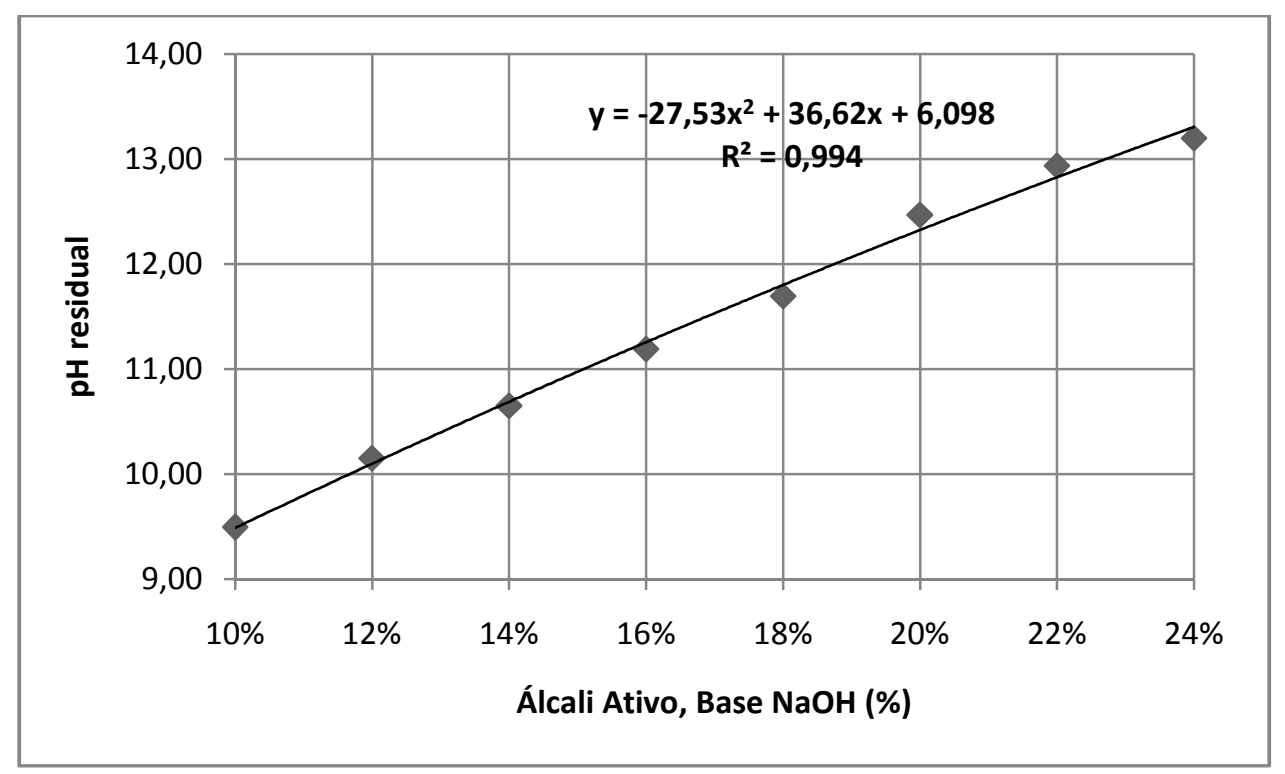

Figura 11: pH residual / Álcali Ativo, Base $\mathrm{NaOH} \mathrm{( \% )}$

\subsubsection{Lignina residual}

Representa a quantidade de lignina retirada durante o processo de polpação. Pode-se fazer uma analogia com os parâmetros Álcali Ativo Residual e pH do licor negro. A figura 12 mostra que a quantidade de lignina residual acompanhou o aumento das cargas de álcali aplicadas tendendo estabilizar nas cargas mais altas. 


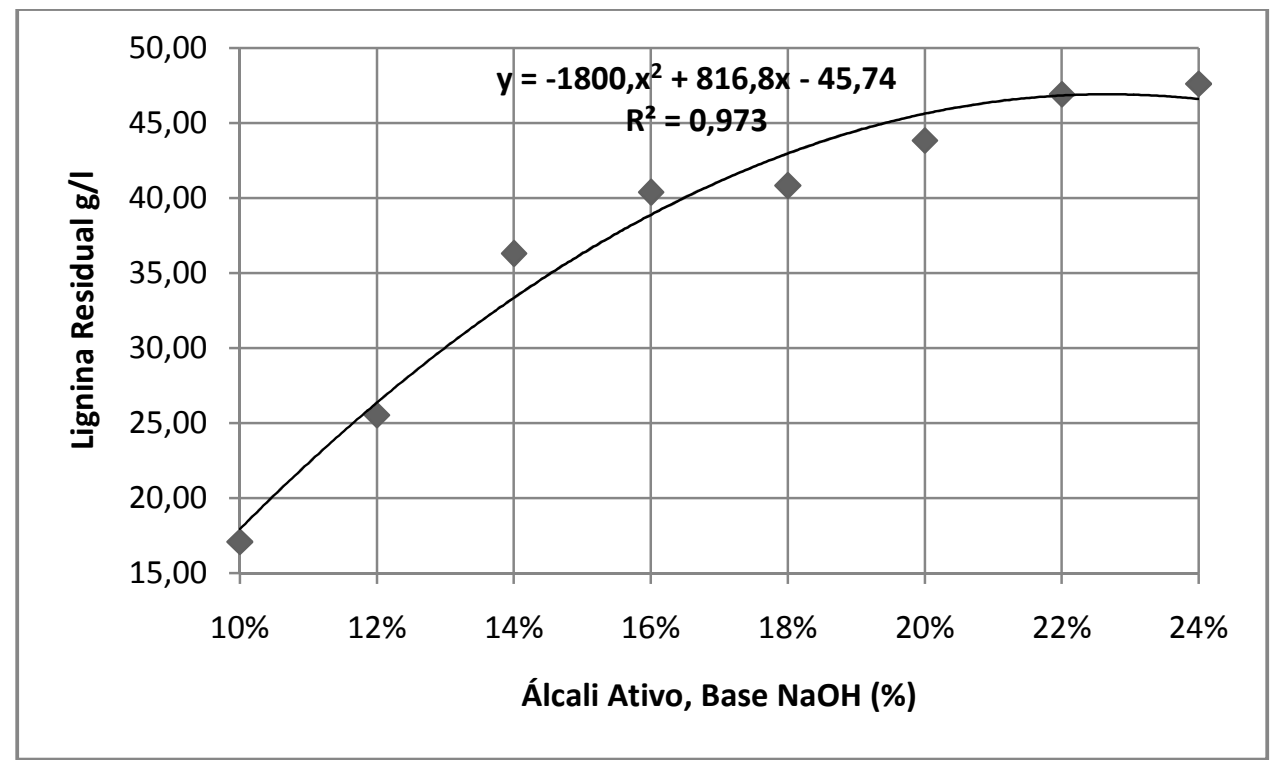

Figura 12: Lignina Residual (g/l) / Álcali Ativo, Base NaOH (\%). 


\subsection{Análise da polpa}

\subsubsection{Análise estatística}

Na tabela 9 encontra-se os resultados médios (M), desvio padrão (S) e coeficientes de variação (CV) da análise estatística do licor negro, nota-se que para os parâmetros nível de regeitos e ácidos hexenurônicos encontram-se valores de coeficiente de variação muito grandes.

Tabela 9: Análise estatística para os resultados dos parâmetros da polpa celulósica.

\begin{tabular}{|c|c|c|c|c|c|c|c|c|c|}
\hline & & \multicolumn{8}{|c|}{ Álcali Ativo (\%), Base $\mathrm{NaOH}$} \\
\hline & & 10 & 12 & 14 & 16 & 18 & 20 & 22 & 24 \\
\hline \multirow{3}{*}{$\begin{array}{l}\text { Rendimento } \\
\text { Bruto (\%) }\end{array}$} & $M$ & $52,25 \mathrm{a}$ & 48,36 a & $43,12 \mathrm{~b}$ & $38,77 \mathrm{c}$ & $37,12 \mathrm{~cd}$ & $36,56 \mathrm{~cd}$ & $35,88 \mathrm{~cd}$ & $34,61 d$ \\
\hline & $\mathrm{S}$ & 1,17 & 2,75 & 0,94 & 1,20 & 1,28 & 1,08 & 0,82 & 0,74 \\
\hline & CV (\%) & 2 & 6 & 2 & 3 & 3 & 3 & 2 & 2 \\
\hline \multirow{3}{*}{$\begin{array}{l}\text { Rendimento } \\
\text { Depurado (\%) }\end{array}$} & $M$ & 51,24 a & 47,83 a & $42,98 \mathrm{~b}$ & $38,70 \mathrm{c}$ & $37,11 \mathrm{~cd}$ & $36,55 \mathrm{~cd}$ & $35,87 \mathrm{~cd}$ & $34,61 \mathrm{~d}$ \\
\hline & $\mathrm{S}$ & 1,17 & 2,75 & 0,94 & 1,20 & 1,28 & 1,08 & 0,82 & 0,74 \\
\hline & CV (\%) & 2 & 6 & 2 & 3 & 3 & 3 & 2 & 2 \\
\hline \multirow{3}{*}{$\begin{array}{c}\text { Nível de } \\
\text { Regeitos (\%) }\end{array}$} & $M$ & $1,01 \mathrm{a}$ & $0,53 \mathrm{~b}$ & $0,15 \mathrm{c}$ & $0,06 \mathrm{c}$ & $0,00 \mathrm{c}$ & $0,01 \mathrm{c}$ & $0,00 \mathrm{c}$ & $0,00 \mathrm{c}$ \\
\hline & $S$ & 0,28 & 0,19 & 0,13 & 0,03 & 0,01 & 0,02 & 0,01 & 0,00 \\
\hline & CV (\%) & 28 & 35 & 91 & 45 & 128 & 120 & 351 & 173 \\
\hline \multirow{3}{*}{$\begin{array}{c}\text { Ácidos } \\
\text { Hexenurônicos } \\
\mu \mathrm{mol} \text { g-1 }\end{array}$} & $M$ & $0,23 a$ & $1,12 \mathrm{ab}$ & $1,97 \mathrm{~b}$ & $6,77 c$ & $9,55 d$ & $10,60 \mathrm{de}$ & $10,86 \mathrm{e}$ & $11,31 \mathrm{e}$ \\
\hline & $S$ & 0,20 & 0,06 & 0,79 & 3,95 & 0,72 & 0,09 & 0,10 & 0,07 \\
\hline & CV (\%) & 90 & 5 & 40 & 58 & 8 & 1 & 1 & 1 \\
\hline \multirow{3}{*}{ Número Kappa } & $M$ & 80,88 a & $66,52 \mathrm{~b}$ & $49,94 \mathrm{c}$ & $30,84 \mathrm{~d}$ & $20,92 \mathrm{de}$ & 14,74 ef & 12,86 ef & $8,78 \mathrm{f}$ \\
\hline & $\mathrm{S}$ & 6,98 & 5,26 & 2,58 & 4,09 & 2,00 & 1,30 & 2,00 & 1,65 \\
\hline & CV (\%) & 9 & 8 & 5 & 13 & 10 & 9 & 16 & 19 \\
\hline \multirow{3}{*}{$\begin{array}{c}\text { Viscosidade } \\
\text { CP }\end{array}$} & $M$ & - & - & - & 57,34 a & 52,80 a & $41,93 \mathrm{~b}$ & $30,42 \mathrm{c}$ & $19,12 d$ \\
\hline & $S$ & - & - & - & 1,63 & 0,72 & 3,29 & 1,96 & 1,53 \\
\hline & CV (\%) & - & - & - & 3 & 1 & 8 & 6 & 8 \\
\hline
\end{tabular}

Nota: * Os valores seguidos de mesma letra se igualam estatisticamente pelo teste de Tukey ao nível de significância a $5 \%$.

Sinal convencional utilizado:

- Não de aplica ao dado numérico.

$\mathrm{M}=$ Média

$\mathrm{S}=$ Desvio Padrão

$\mathrm{CV}=$ Coeficiente de Variação

\subsubsection{Rendimento}

$\mathrm{Na}$ avaliação de processos de polpação, o rendimento é um parâmetro de fundamental importância por estar relacionado ao consumo específico de madeira bem como a geração de sólidos para queima em caldeira. O consumo específico de madeira é de especial importância, pois a madeira representa entre 60 e $80 \%$ do custo de produção 
de polpa celulósica e ainda impacta na intensidade das atividades silviculturais; maiores rendimentos industriais implicam em menores consumos específicos de madeira e em menores custos de produção de polpa celulósica (FERNANDÉZ, 2010).

\subsubsection{Rendimento bruto}

O rendimento bruto expressa a quantidade de polpa celulósica obtida ao final do processo de polpação em comparação com a madeira alimentada inicialmente, sem levar em consideração o teor de rejeitos ainda presentes na polpa.

Os resultados obtidos estão expressos na figura 13. Nota-se que o rendimento cai à medida que a carga de álcali é aumentada. Os rendimentos mais altos pode ser explicado pela falta de álcali comprovada na análise do $\mathrm{pH}$ do licor negro e álcali ativo residual.

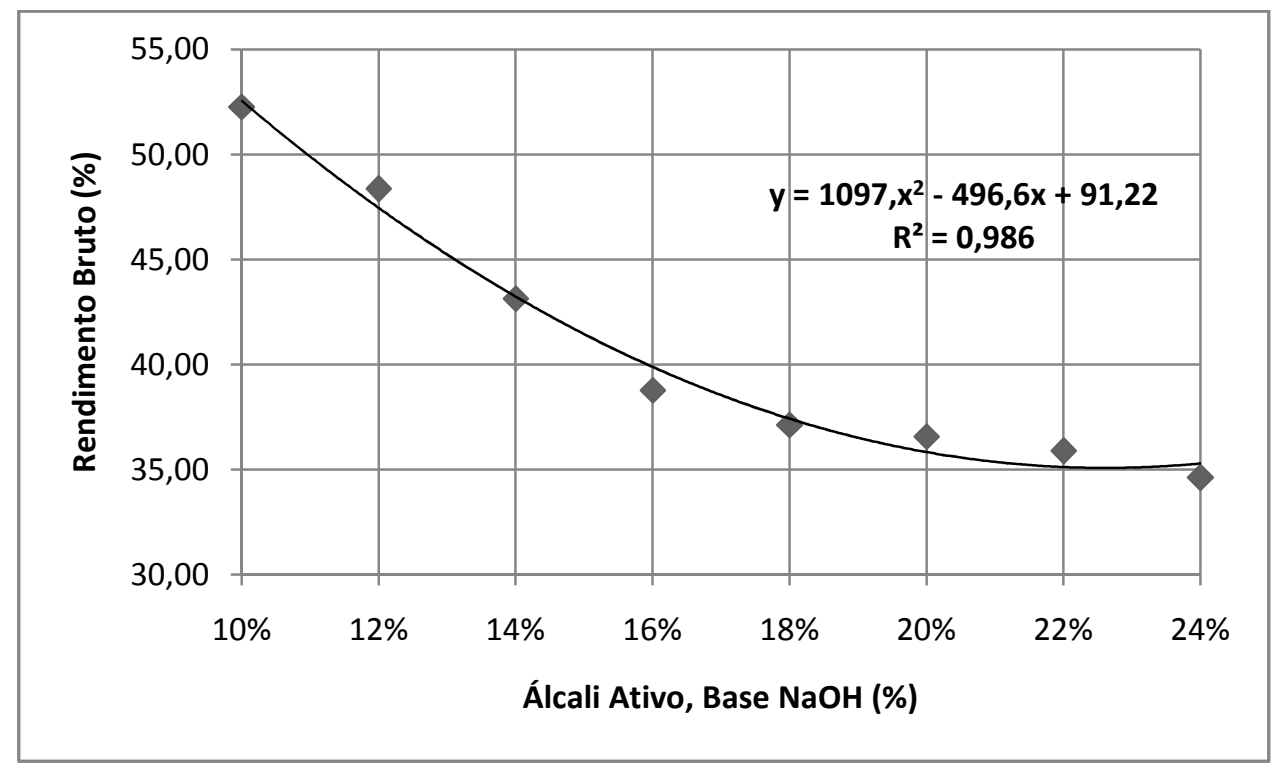

Figura 13: Rendimento Bruto (\%) / Álcali Ativo, Base $\mathrm{NaOH}(\%)$

\subsubsection{Rendimento depurado}

O rendimento depurado representa a quantidade de polpa celulósica obtida após o processo de depuração, ou seja, livre de rejeitos. Sendo assim se constitui um parâmetro de fundamental importância no processo de polpação.

Os resultados obtidos estão expressos na figura 14. Nota-se que o rendimento depurado tem os valores bem próximos aos valores do rendimento bruto assim como as 
curvas tem o mesmo comportamento. Isso se deve ao baixo teor de rejeitos explicado na figura 15 .

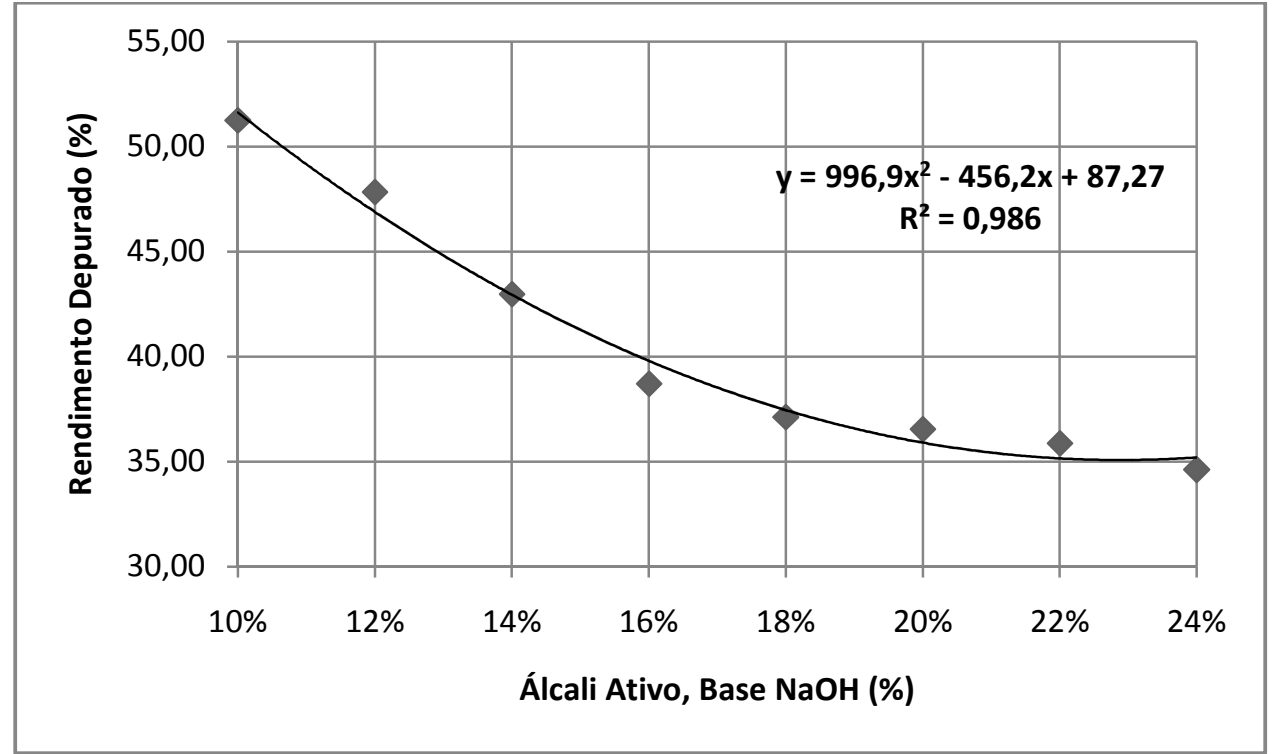

Figura 14: Rendimento Depurado (\%) / Álcali Ativo, Base $\mathrm{NaOH}(\%)$

\subsubsection{Teor de rejeitos}

Análogo ao rendimento, a determinação do teor de rejeitos é de fundamental importância no dimensionamento do sistema de depuração, bem como na definição da estratégia para destinação dos rejeitos.

O teor de rejeitos no processo de polpação está relacionado às características da matéria-prima e aos parâmetros do processo de polpação, principalmente tempo e temperatura de impregnação, fator H e carga alcalina (ALMEIDA, 2003).

Para todos as cargas de álcali aplicadas os teores de rejeitos foram bastante baixos (Figura 15) o que por sua vez estão relacionados com uma boa impregnação e difusão do licor na madeira durante o processo de polpação devido a alta porosidade do material em estudo. 


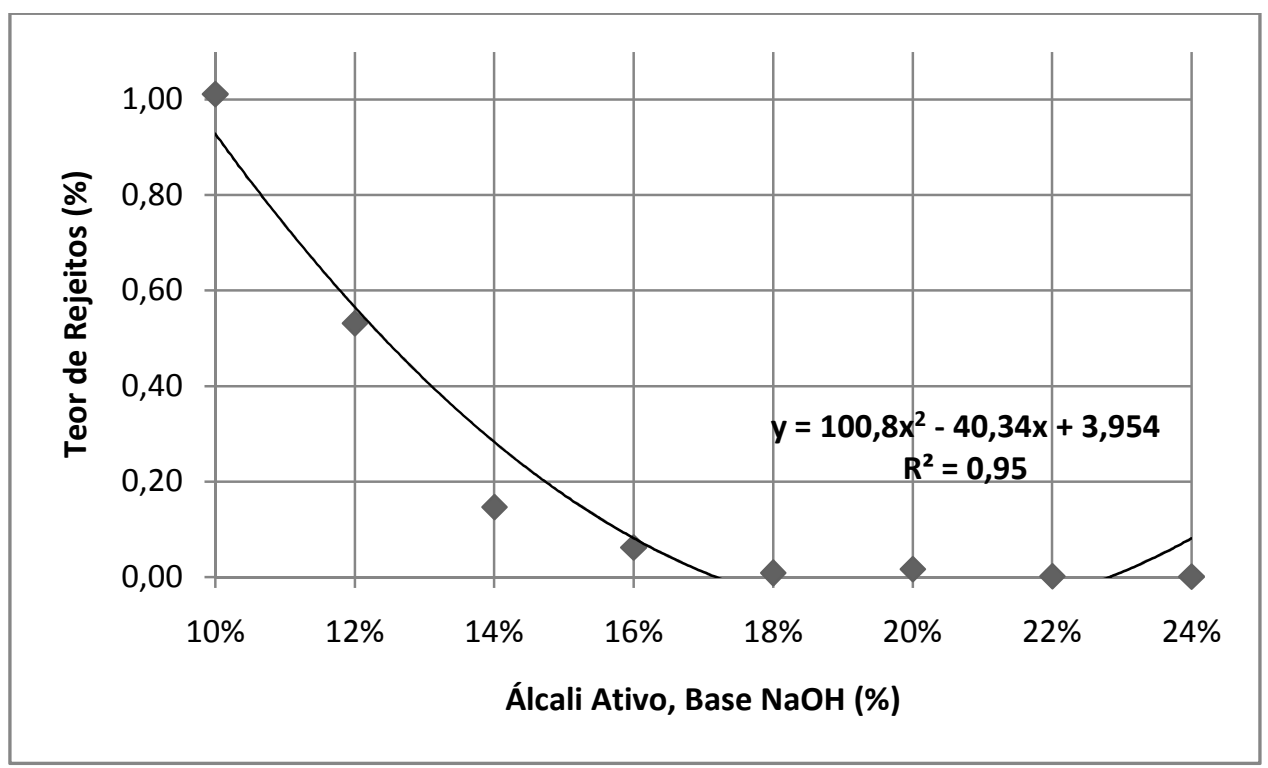

Figura 15: Teor de Regeitos (\%) / Álcali Ativo, Base $\mathrm{NaOH}(\%)$

\subsection{4. Ácidos hexenurônicos}

Os ácidos hexenurônicos são formados durante a polpação alcalina através de modificações do ácido 4-O metil-glucuronico, presente na xilanase. As condições de polpação que mais influenciam o teor de ácidos hexenurônicos na polpa são álcali ativo e temperatura. A formação de ácidos hexenurônicos não é desejável, especialmente para polpas destinadas ao processo de branqueamento, já que os mesmos, além de consumirem os reagentes químicos, também causam reversão de alvura (VENTORIM et al., 2009).

De acordo com Daniel et al. (2003) os ácidos hexenurônicos formados durante a polpação podem ser simultaneamente degradados em meio alcalino ou parcialmente eliminados como uma resultante da dissolução da xilana.

O teor de ácidos hexenurônicos presente nas polpas avaliadas neste trabalho (Figura 16) são baixos se comparados com as quantidades presentes em polpas kraft de eucalipto derivadas de processos modificados experimentais, os quais estão na faixa de $55-75 \mu \mathrm{mol} / \mathrm{g}$ de polpa, equivalendo a concentração de 6 a 8 unidades de número kappa (COLODETTE, 2007). 


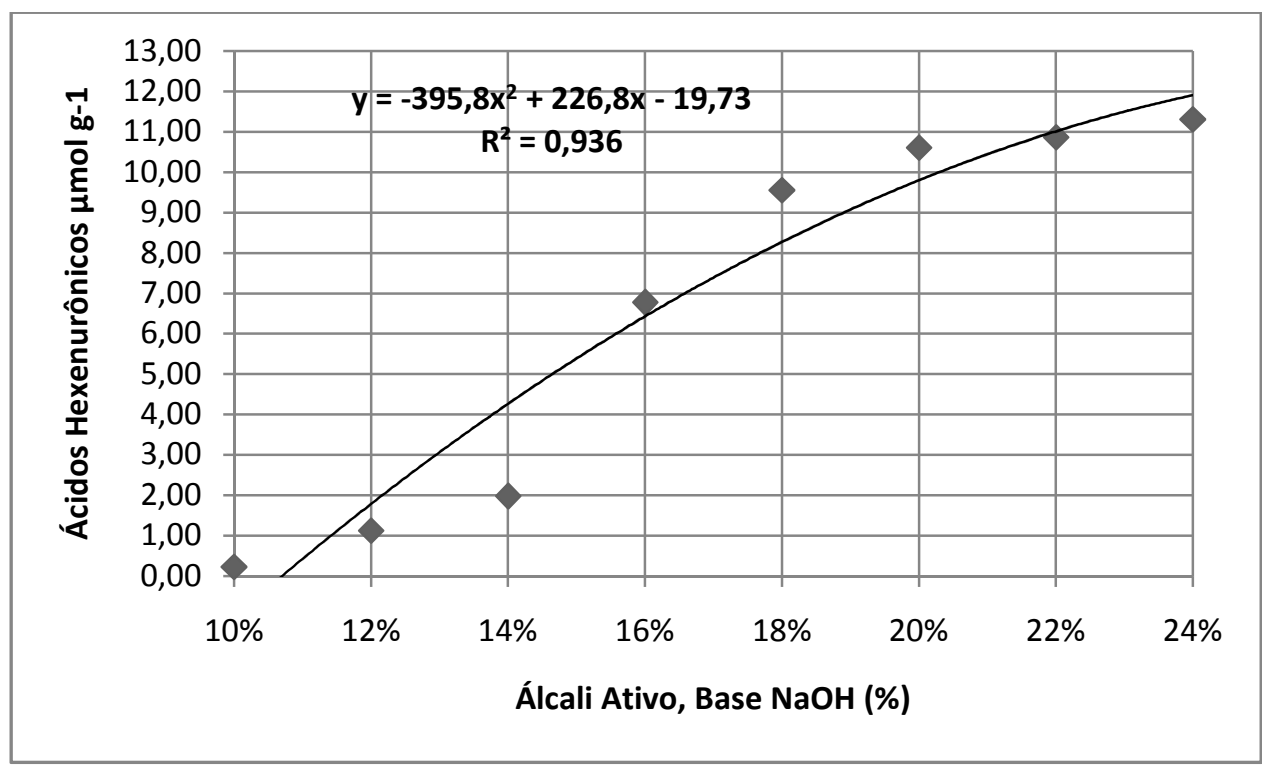

Figura 16: Ácidos Hexenurônicos $\mu \mathrm{mol}$ g-1 / Álcali Ativo, Base NaOH (\%)

\subsubsection{Número kappa}

O número kappa é definido como o volume de solução de permanganto de potássio $0,1 \mathrm{~N}$ em mililitros, consumido por um grama de pasta absolutamente seca, sob condições específicas e corrigidas para um consumo relativo de $50 \%$ de permanganato (D’ALMEIDA, 1988).

Para o parâmetro número kappa, uma tendência decrescente é notada com o aumento do nível de álcali ativo, como mostrado na figura 17.

Alencar et al. (2002) afirmou que aumentar a carga de álcali no processo de polpação conduz para a redução do número kappa, representando uma alta remoção de lignina. Porém já é sabido que se pode aumentar o álcali a níveis altos e nunca se alcançará o kappa zero, apenas aumentará os custos e danificará a qualidade da polpa.

De acordo com Gonçalez (2009) polpas com número kappa entre 15 e 35 podem ser branqueáveis produzindo papéis para uso fino, número kappa de 30 a 70 são polpas não branqueáveis destinadas à produção de papeis para outros fins como embalagens e número kappa de 70 a 120 são polpas com alta concentração de lignina e devem ser destinas a produção de papelão.

Pelos parâmetros estabelecidos pelo autor supracitado temos polpas branqueáveis nas cargas de álcali ativo de 16, 18 e 20\%, polpas não branqueáveis nas cargas de álcali 
ativo de 12,14 e $16 \%$ e polpa para produção de papelão com carga de $10 \%$ de álcali ativo.

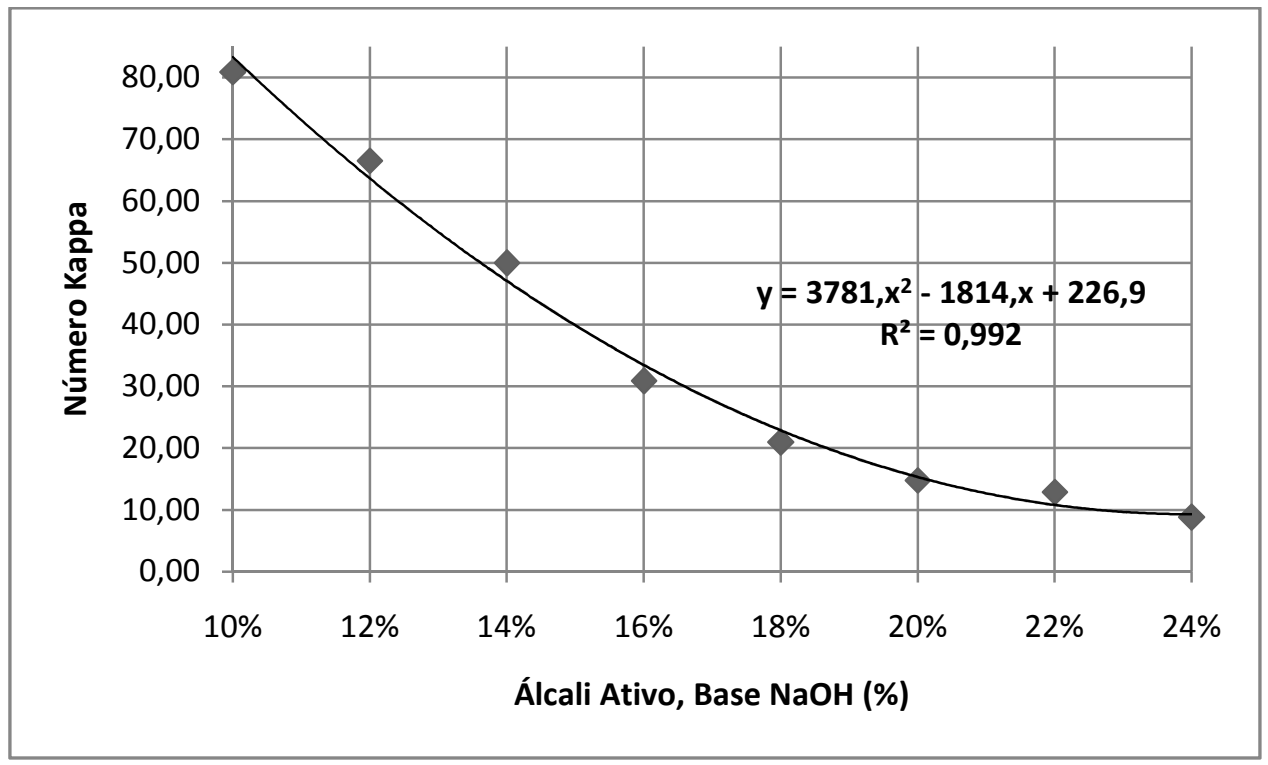

Figura 17: Número kappa / Álcali Ativo, Base NaOH (\%)

\subsubsection{Viscosidade}

Viscosidade da polpa é um parâmetro amplamente usado no controle da qualidade da polpa em diferentes fazes do processo de produção. O parâmetro viscosidade é associado com o grau médio de polimerização e o peso molecular correspondente dos polímeros celulose e hemiceluloses, esta medição está sendo usada indiretamente para estimar o grau de polimerização e em que medida os carboidratos são quebrados durante a fase em que a polpa celulósica é obtida. Deste modo, geralmente, maior viscosidade indica maior preservação dos carboidratos e, consequentemente, maior resistência física, principalmente aquelas que dependem do vínculo entre as fibras (Almeida, 2003).

A figura 18 mostra os valores obtidos para o parâmetro viscosidade da polpa e seu comportamento, dependendo da carga de álcali aplicada. Os resultados alcançados variaram de 19,12 até 57,34 cP. Em cozimento Kraft de P. taeda Kalinke (2010) encontro valores entre 24,3 e 31,7 cP o que mostra certa sobreposição de valores de viscosidade entre as duas matérias primas.

A maior viscosidade obtida ocorre na menor carga de álcali devido ao menor ataque a fração de carboidrato da matéria-prima. Geralmente altas viscosidades indicam 
uma maior preservação dos carboidratos e, por conseguinte, propriedades de resistência físico-mecânicas melhores, principalmente aquelas que dependem do enfeltramento de fibras, mas deve-se destacar que a utilização da viscosidade como parâmetro de qualidade da polpa é questionável conforme demonstrado por vários autores (CARNEIRO et al., 1995)

De acordo com Gonçalez (2009) para as viscosidade de 15 a $20 \mathrm{cP}$ as polpas são propícias a branqueamento e de 35 a 40 cP são polpas não branqueáveis. Seguindo essa graduação temos polpa branqueável apenas na última carga (24\% de álcali ativo, base $\mathrm{NaOH})$.

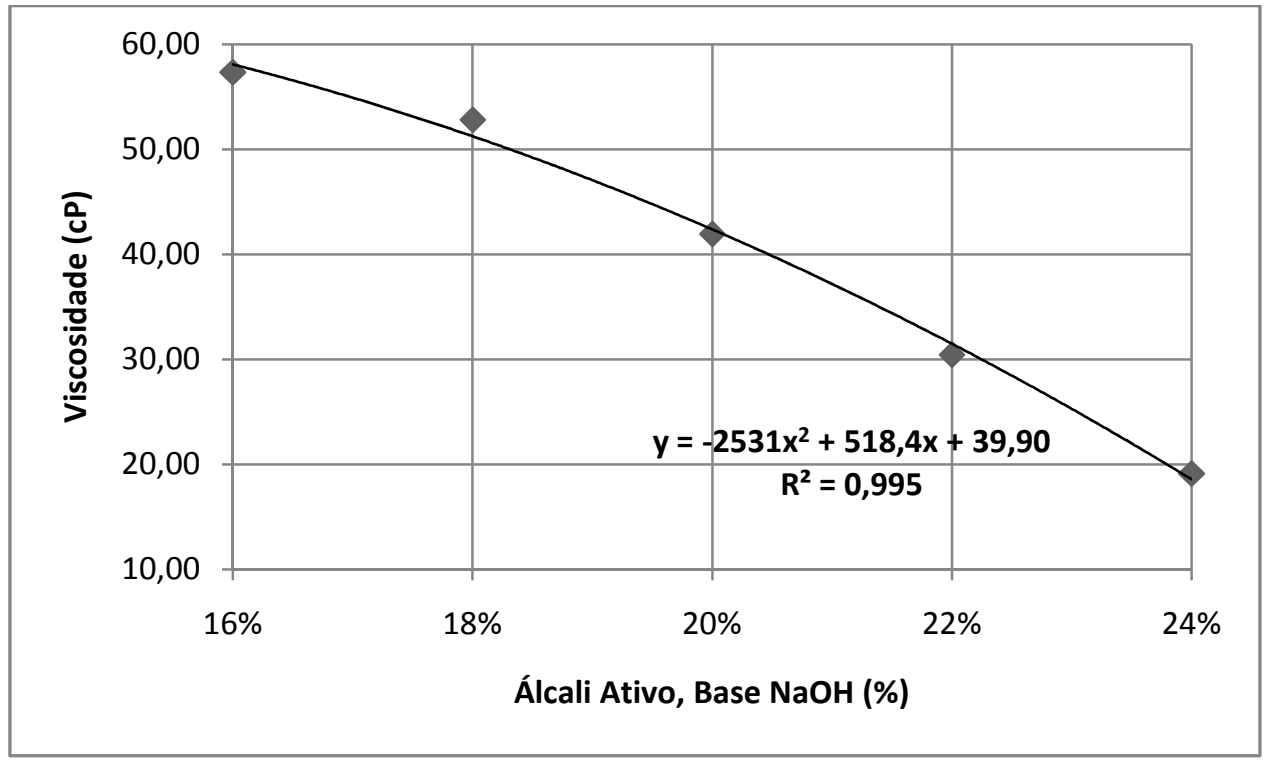

Figura 18: Viscoisdade (mPa.s) / Álcali Ativo, Base $\mathrm{NaOH}(\%)$ 


\section{CONCLUSÕES E SUGESTÕES}

As dimensões dos cavacos de bambu (Bambusa vulgaris Schrad. ex J.C. Wendl.) são compatíveis para produção de celulose, favorecendo a impregnação no cozimento.

A densidade básica apontou valor médio de $0,494 \mathrm{~g} / \mathrm{cm}^{3}$, tal densidade favorece a penetração e distribuição do licor de cozimento durante a polpação.

As dimensões médias de fibras relacionadas com os índices de qualidade indicam para uma alta qualidade de polpa celulósica produzida.

O bambu apresentou alta porcentagem de holocelulose e valores médios de lignina e baixos de extrativos totais quando comparados com a madeira de Pinus spp. e Eucalyptus spp.

As quatro primeiras cargas de álcali foram insuficientes para deslignificação e impedimento da precipitação da lignina de acordo com a análise do álcali ativo residual. As cargas de $16 \%$ a $24 \%$ contemplam a necessidade de álcali para impedimento da precipitação da lignina e deslignificação eficiente de acordo com a análise do $\mathrm{pH}$ do licor negro.

Para o rendimento total foram obtidos valores de 52,25 a $34,61 \%$. O material estudado apresentou valores de teor de rejeito praticamente insignificantes, sendo um ponto positivo para o processo de polpação.

Os ácidos hexenurônicos encontrados são baixos, tal fato facilita-rá o branqueamento da polpa celulósica.

No processo de polpação verificou-se que a maior variação de número kappa ocorreu entre os cozimentos de 12 e $14 \%$ de álcali ativo, havendo um aumento de carga alcalina resulta em uma diminuição de 17 pontos de número kappa. A curva do número kappa apresentou queda expressiva com o aumento das cargas, variando de 80,88 a 8,8 , mostrando a influência das cargas de álcali.

A viscosidade da polpa teve comportamento inversamente proporcional em relação às cargas de álcali aplicadas, variando de 57,34 a 19,12 cP.

A espécie B. vulgaris apresentou potencial para produção de celulose Kraft. No entanto recomenda-se, para os próximos estudos, aumentar o número de repetições e prosseguir com a caracterização das demais propriedades do papel (físicas, mecânicas, óticas, químicas, elétricas e anatômicas). 


\section{REFERÊNCIAS BIBLIOGRÁFICAS}

ALENCAR, G.S.B.; BARRICHELO, L.E.G.; SILVA Jr., F.G. Qualidade da madeira do híbrido de E. grandis x E. urophylla e seleção precoce. In:35 Congresso e Exposição Anual de Celulose e Papel. Anais, 2002.

ALMEIDA, F.S. Influência da carga alcalina no processo de polpação Lo-Solids para madeira de eucalipto. 2003.114 p. Dissertação (Mestrado em Recursos Florestais) - Escola Superior de Agricultura "Luiz de Queiroz”, Universidade de São Paulo, Piracicaba, 2003.

ANDRADE, A.S. Qualidade da madeira, celulose e papel em Pinus taeda L.: Influência da idade de classe de produtividade. 2006. 107 p. Dissertação (Mestrado em Ciências Florestais) - Universidade Federal do Paraná, Curitiba, 2006.

ANDRADE, J.O.M.; ZVINAKEVICIUS, C.; FOELKEL, C.E.B. Estudos sobre a influência da espessura dos cavacos de eucalipto sobre a qualidade da celulose kraft correspondente. O Papel, São Paulo, v. 39, n. 10, p. 55-59, out. 1978.

AZZINI, A.; ARRUDA, M.C.Q.; CIARAMELlO, D.; SALGADO, A.L.B.; TOMAZELLO, M.F. Produção conjunta de fibras celulósicas e etanol a partir do bambu. Bragantia, Campinas, 46(1):17-25, 1987.

BARRICHELO, L.E.G.; BRITO. J.O. A utilização da madeira na produção de celulose. Circular Técnica, IPEF, Piracicaba, № 68, 1979.

BIOSTAT; Copoyright (C) 2001 - 2009 AnalystSoft, 2009. 
BONILLA, O. H. Análises quantitativas da produção de bambusa vulgares Scharder ex Wendland for vulgares no estado da Paraíba. 1991. 89 f. Dissertação (Mestrado em Botânica) - Universidade Federal Rural de Pernambuco, Recife.

BRACELPA - ASSOCIAÇÃO BRASILEIRA DE CELULOSE E PAPEL. Relatório Anual 2009/2010. Disponível em: <http://www.bracelpa.org.br/bra2/sites/default/files/estatisticas/rel2009.pdf.> Acesso em: 09 dez. 2010.

BRASIL, M.A.M.; FOEKEL C.E.B.; BARRICHELO L.E.G.; HIGA A.R. Variação dascaracterísticas e das propriedades físico-mecânicas com refinação da celulose sulfato de madeira de Eucalyptus saligna SMITH. IPEF, Piracicaba, n. 5, p. 33$45,1972$.

BRITO, J.O.; TOMAZELLO FILHO, M.; SALGADO, A.L. Estudo sobre a constituição química do Bambusa vulgaris, visando a produção de polpa celulósica. O Papel, São Paulo, v. 47, n. 10, p. 64-68, out. 1986.

BRODERICK, G.; HÉROUX, Y.; CACCHIONE, E. The importance of distribution statistics in the characterization of the chip quality. In: PULPING CONFERENCE, 1996, Atlanta. Proceedings... Atlanta: TAPPI Press, 1996. p. 535-549.

CAMPANELA, F.L.; BUSON, M.A.; SPOSTO, R.M. A influência da cura com mistura solta no preparo do kraftterra para a produção de blocos de terra compactada. Revista de Pesquisa Aplicada à Engenharia. Brasília, vol. 1, n. 1, 2008.

CARNEIRO, C.J.G., WEHR, T.R.; MANFREDI, VAIL, Efeito da viscosidade nas propriedades físico mecânicas de polpas branqueadas. In: CONGRESSO 
ANUAL DE CELULOSE E PAPEL, 28, 1995, São Paulo. Anais... São Paulo: ABTCP, 1995. p.227-233.

CARVALHO, W.A.T. Tecnologia das Matérias-Primas Celulósicas Brasileiras. Instituto Nacional de Tecnologia. Rio de Janeiro, 1960. 123p.

CASTRO E SILVA, R.M. O bambu no Brasil e no mundo. Disponivel em: $<$ http://www.institutoeu.com.br/arquivos/downloads/Bambu_no_Brasil_e_no_M undo_56403.pdf> Acesso em: 05 jan. 2010.

CHAI, X.-S.; LUO, Q.; YOON, S-H.; ZHU, J.Y. The fate hexenuronic acid groups during kraft pulping of hardwoods. In: INTERNATIONAL SYMPOSIUM ON WOOD AND PULPING CHEMISTRY, 11. Volume II: Poster Presentations... France. June 11 to 14,2001 b. p. 257-260.

COLODETTE, J.L. Effect of pulp delignification degree on fibre line performance and bleaching effluent load. Bioresources, Raleigh, v. 2, n. 2, p. 223-234, 2007.

D’ALMEIDA, M. L. O. (Ed.). Celulose e papel: tecnologia de fabricação da pasta celulósica e do papel. 2. ed. São Paulo: SENAI/IPT, 1988. v. 1 e v. 2, 964p.

DANIEL, I.G.; PASCOAL NETO, C.; EVTUGUIN, D.V.; SILVESTE, A.J.D. Conteúdo de ácidos hexenurônicos em polpas kraft de Eucalyptus globulus: variação com as condições de polpação e efeito na branqueabilidade ECF. O Papel, São Paulo, v. 64, n.7, p. 4-12, jul. 2003.

FERNANDÉZ, M. A. V. Avaliação dos processos de polpação soda- Antraquinona e bissulfito-base magnésio para bambu. 2010. 91p. Dissertação (Mestrado em Ciências Florestais) - Escola Superior de Agricultura "Luiz de Queiroz", Universidade de São Paulo, Piracicaba, 2010. 
FILHO, A. P.; BADR, O. Biomass resources for energy in North-Eastern Brazil.

Applied Energy 77, p. 51-67. 2004.

FLORA BRASILIENSIS. Informações disponíveis no site <http:// florabrasiliensis.cria.org.br/>. Acesso em: $10 \mathrm{dez} .2010$.

FOELKEL C.E.B.; BARRICHELO, G.E.L. Tecnologia de celulose e papel. Piracicaba: IPEF, 1975. 207 p.

FOELKEL, C.; MORA, E.; MENOCHELLI, S. Densidade básica: sua verdadeira utilidade como índice de qualidade da madeira de eucalipto para a produção de celulose. O Papel, São Paulo, v. 53, n. 5, p. 51992.

FUZETO, A. P. Determinação do teor de lignina em amostras vegetais através de três métodos com digestibilidade in vitro. 2003. 74p. Dissertação (Mestrado em Nutrição Animal) - Faculdade de Medicina Veterinária e Zootecnia, Universidade de São Paulo, Pirassununga, 2003.

GOMES, F.A.; Avaliação dos processos Kraft convencional e Lo-Solids® para madeira de Pinus taede. 2009. 99p. Dissertação (Mestrado em Ciências Florestais) - Escola Superior de Agricultura "Luiz de Quiroz”, Universidade de São Paulo,Piracicaba, 2009.

GOMIDE, J.L.; COLODETTE, J.L.; OLIVEIRA, R.C. Influência do álcali ativo e da temperatura na polpação Kraft de Bambusa vulgaris. Revista Árvore, Viçosa, v.5, n.2, p.181-193, 1981. 
GOMIDE, J.L.; COLODETTE, L.J.; OLIVEIRA, R.C. Estudos das potencialidades do Bambusa vulgaris para produção de papéis tipo Kraft. O papel, São Paulo, v. 28, n. 7, p. 38-42, 1982.

GONCALEZ, J.C.; Nota de aula expositiva. Disciplina Celulose e Papel. Brasília: UnB - EFL, 2009 (aulas do primeiro semestre).

GONCALEZ, J. C.; FRAGA, D. G.; SILVA Jr, F. G. Avaliação da Polpação soda de Pinus taeda com a adição de Antraquinona. In: Congresso Ibero Americano de Investigadores de Celulosa y Papel, 2002, São Paulo SP. Congresso Ibero Americano de Celulosa. Anais... São Paulo, 2002. v. 1. p. 10-20.

GULLICHSEN, J.; KOLEHMAINEN, H.; SUNDQVIST, H. On the nonuniformity of the kraft cook. Paperi Ja Puu, Helsinki, v. 74, n. 6, p. 486-490, 1992.

IPEF - INSTITUTO DE PESQUISAS FLORESTAIS. Estatísticas. Disponível em: <http://www.ipef.br/>. Acesso em: 30 mar. 2010.

KALINKE, M. Avaliação da adição da antraquinona no cozimento kraft de Pinus taeda fixando o número kappa. In: $43^{\circ}$ CONGRESSO ANUAL DE CELULOSE E PAPEL, ABTCP. 2010.

KLEINE, H.J. Desenvolvimento Brasileiro em Fibra Longa. O Papel. 63(5): 52-53. São Paulo. 2002.

KLOCK, U. Nota de aula expositiva Disciplina Polpa e Papel. UFPR - DEIM. Disponível em: <www.madeira.ufpr.br/disciplinasklock> Acesso em: 8 ago. 2010. 
LOMBARDO, C.; PADILLA, A. Manual teórico práctico de conversión química de La madera y química ambiental. Mérida: Universidad de Los Andes, Facultad de Ciencias Forestales y Ambientales, 1998. 55 p.

LONDONO, X. Evaluation of Bamboo Resources in Latin America. A Summary of the Final Report of Project N 96-8300-01-4 - International Network for Bamboo and Rattan (1999).

MOGOLLÓN, G.; AGUILERA, A. Guía teórica y práctica de morfología de la fibra. Mérida - Venezuela:Universidad de Los Andes, 2002. 48p.

MORESCHI, J.C. Levantamento da qualidade da madeira em plantações artificiais de Pinus elliotti nos estados do Sul do Brasil. 1975. 181 p. Dissertação (Mestrado em Ciências) - Universidade Federal do Paraná, Curitiba, 1975.

MURAKAMI, C.H. O bambu: matéria prima do futuro. Boletim Florestal, São Paulo, v. 1, n. 6, p. 5, dez. 2007.

NETTO, L.G.; GIANNETTI, B.F.; ALMEIDA, C.M.; BONILLA, S.H. Determinação dos fluxos de $\mathrm{CO} 2$ de uma plantação comercial de bambu no Brasil: Oportunidades para a diminuição da emissão de CO2. In: SIMPÓSIO DE ENGENHARIA DE RODUÇÃO, 15., 2008, São Paulo. Anais... São Paulo, 2008. 1 CD-ROM.

PAULA, J.E.; ALVES, J.L.H. Madeiras nativas: anatomia, dendrologia, dendrometria, produção, uso. Brasília: Fundação Mokiti Okada, 1997. 541 p.

PEREIRA, J.C.D.; STURION, J.A.; HIGA, A.R.; HIGA, R.C.V.; SHIMIZU, J.Y. Características da madeira de algumas espécies de eucalipto plantadas no Brasil. 
Colombo: Embrapa Florestas, 2000. 113p. (Embrapa Florestas. Documentos, $38)$.

PEREIRA, M.A.R.; BERALDO, A.L. Bambu de corpo e alma. Bauru: Editora Canal 6, 2007. 239 p.

SANTOS, S.R.; Influência da qualidade da madeira de híbridos Eucalyptos grandys x Eucalyptos urophylla e do processo Kraft de polpação na qualidade da polpa banqueada. 2005. 178p. Dissertação (Mestrado em Ciências Florestais) Escola Superior de Agricultura "Luiz de Queiroz", Universidade de São Paulo, Piracicaba, 2005.

SBRT - SERVIÇO BRASILEIRO DE RESPOSTAS TECNICAS. Cultura de bambu. Disponivel em: < http://www.respostatecnica.org.br/resposta.do/crtebambusal> Acesso em: 15 out. 2009.

SHIMOYAMA, V.R.S.; WIECHETECK M.S.S. Características da Madeira e da pasta termomecânica de Pinus patula var. tecunumanii para produção de papel imprensa. Série Técnica IPEF, Piracicaba, v. 9, n. 27, p. 63-80, ago. 1993.

SILVA Jr, F.G. Polpação kraft de eucalipto com adição de antraquinona, polissulfetos e surfactante. 1997. 184 p. Tese (Doutorado em Engenharia Química) - Faculdade de Engenharia de Química, Universidade Estadual de Campinas, Campinas, 1997.

SILVA Jr. F.G.; McDONOUGH, T.J. Polpação Lo-Solids® de Eucalipto: Efeito do Ritmo de Produção. In: $34^{\circ}$ CONGRESSO ANUAL DE CELULOSE E PAPEL, ABTCP 16p. 2001. 
TECHNICAL ASSOCIATION OF PULP AND PAPER INDUSTRY. Test methods. Atlanta: Tappi Press, 1998.

VASCONCELOS, F.S.R. Avaliação do processo SuperBatch ${ }^{\mathrm{TM}}$ de polpação de Pinus taeda. 2005. 106p. Dissertação (Mestrado em Ciências Florestais) Escola Superior de Agricultura "Luiz de Quiroz", Universidade de São Paulo, Piracicaba, 2005.

VELEZ, S. Grow your own house - Simon Velez and Bamboo Architecture. Vitra Design Museum / ZERI / C.I.R.E.C.A. 2001.

VENTORIM, G.; CARASCHI, J.C.; COLODETTE, J.L.; GOMIDE, J.L. A influência dos ácidos hexenurônicos no rendimento e na branqueabilidade da polpa Kraft. Química Nova, São Paulo, v. 15, n. 2, p. 1-5, 2009.

VIEIRA, S. Introdução à bioestatística. 3. ed. Rio de Janeiro: Campus, 1980. 196p.

WEHR, T.R.; BARRICHELO, L.E.G. Cozimentos kraft com madeira de Eucalyptus grandis de diferentes densidades básicas e dimensões de cavacos. O Papel, São Paulo, v. 54, n. 5, p. 33-41, maio 1993. 
APÊNDICES 


\section{APÊNDICE A \\ Determinação Simultânea de Extrativos Totais, Lignina e Holocelulose}

1. Pesar o equivalente a $2 \mathrm{~g}$ a.s. de serragem e transferir para saquinho de papel filtro;

2. Colocar a amostra no corpo do extrator;

3. Fazer a extração com álcool:tolueno (1:2) e álcool $96^{\circ} \mathrm{GL}$, durante 8 horas em cada solvente, deixando secar ao ar após cada extração;

4. Ligar o banho-maria e mantê-lo em ebulição;

5. Transferir toda a serragem do saquinho para erlenmeyer de $250 \mathrm{~mL}$;

6. Adicionar $100 \mathrm{~mL}$ de água destilada e colocar o erlenmeyer no banho-maria (que já deverá estar fervendo) e cobri-lo com papel alumínio;

7. Agitar suavemente a cada 15 minutos;

8. Após uma hora filtrar através de cadinho de vidro tarado, transferindo toda a serragem do erlenmeyer para o cadinho;

9. Lavar (descontinuamente) o cadinho com $250 \mathrm{~mL}$ de água quente (quase fervendo);

10. Mantê-lo na estufa até peso constante (normalmente deixa-se de um dia para o outro);

11. Retirar o cadinho da estufa, esperar esfriar em dessecador e pesar;

12. Calcular a percentagem de extrativos através da seguinte equação (7):

$$
\% \text { Extrativos Totais }=\frac{2-(\text { peso a,s.serragem })}{2} * 100
$$

13. Pesar 300mg da serragem livre de extrativos e transferir para erlenmeyer de $250 \mathrm{~mL}$; 14. Adicionar $3 \mathrm{~mL}$ de $\mathrm{H} 2 \mathrm{SO} 472 \%$ (resfriado a $10-12^{\circ} \mathrm{C}$ );

15. Manter em banho-maria a $30 \pm 2{ }^{\circ} \mathrm{C}$ durante 1 hora, misturando freqüentemente com auxíliode bastonete;

16. Retirar do banho-maria e adicionar $84 \mathrm{~mL}$ de água destilada quente; 
17. Colocar o erlenmeyer em autoclave, devidamente vedado com papel alumínio, e regular para $118^{\circ} \mathrm{C}(27 \mathrm{psi})$ durante 50 minutos;

18. Filtrar através de cadinho sinterizado tarado, fazendo um fundo com papel de filtro, transferirtoda a lignina do erlenmeyer para o cadinho;

19. Lavar com $700 \mathrm{~mL}$ de água quente;

20. Não descartar o filtrado para determinação da lignina solúvel;

21. Levar os cadinhos em estufa a $105 \pm 3^{\circ} \mathrm{C}$ até peso constante;

22. Retirar o cadinho da estufa, esperar esfriar em dessecador e pesar, calcular a percentagem de lignina insolúvel conforme equação (8):

$$
\% \text { Lignina Insolúvel }=\frac{(4,53 P(a b s 215 m m-\text { Branco }))-(\text { abs } 280 m m-B r a n c o)}{300 * \text { Peso a.s.Insolúvel }} * 100
$$

23. Do filtrado obtido, transferir para balão volumétrico de $1000 \mathrm{~mL}$ e completar o volume com água destilada;

24. Preparar prova em branco, diluindo $3 \mathrm{~mL}$ de ácido sulfúrico $72 \%$ para $1000 \mathrm{~mL}$;

25. Utilizando cubeta de quartzo e a prova em branco, ajustar o espectrofotômetro em absorbância no comprimento de onda $215 \mathrm{~nm}$ e $280 \mathrm{~nm}$;

26. Prosseguir com a leitura dos filtrados

27. Calcular a percentagem de lignina insolúvel através da equação (9):

$$
\% \text { Lignina Solúvel }=\frac{\text { Peso Seco } \text { Final }}{300} * 100
$$

28. Calcular a percentagem de lignina total somando-se a percentagem de lignina insolúvel e solúvel;

29. Calcular o valor de holocelulose através da equação (10):

$$
\% \text { Holocelulose }=100-\% \text { Liginina Solúvel - \% Extrativos Totais }
$$




\section{APÊNDICE B}

Universidade de São Paulo Escola Superior de Agricultura "Luiz de Queiroz"

Departamento de Ciências Florestais Laboratório de Química Celulose e Energia

COZIMENTO \# 017_08_10

\begin{tabular}{|l|c|}
\hline Data & $26 / 01 / 2010$ \\
\hline \#Cozimento & $017 \_08 \_10$ \\
\hline Projeto & Eraldo Bambu \\
\hline Responsável & Eraldo \\
\cline { 2 - 5 }
\end{tabular}$\quad$\begin{tabular}{l|c|c|c|}
\hline \multicolumn{3}{|c|}{ Condições } \\
\hline Temp Max & 170 & oC \\
\hline Temp Aq. & 90 & min \\
\hline Temp Coz. & 60 & min \\
\hline
\end{tabular}

\begin{tabular}{|l|c|c|}
\hline \multicolumn{3}{|c|}{ Solução Estoque - Concentração } \\
\hline Soda g/L & 138,8 & as $\mathrm{NaOH}$ \\
\hline Sulfeto g/L & 89,8 & as $\mathrm{NaOH}$ \\
\hline
\end{tabular}

\begin{tabular}{|c|c|c|c|c|c|c|c|c|}
\hline \multicolumn{9}{|c|}{ No Reator (digestor) } \\
\hline Capsulas & 1 & 2 & 3 & 4 & 5 & 6 & 7 & 8 \\
\hline Amostra & Bambu & Bambu & Bambu & Bambu & Bambu & Bambu & Bambu & Bambu \\
\hline \%as & 90,88 & 90,88 & 90,88 & 90,88 & 90,88 & 90,88 & 90,88 & 90,88 \\
\hline peso seco & 70 & 70 & 70 & 70 & 70 & 70 & 70 & 70 \\
\hline peso umido & 77,02 & 77,02 & 77,02 & 77,02 & 77,02 & 77,02 & 77,02 & 77,02 \\
\hline AA & $10,0 \%$ & $12,0 \%$ & $14,0 \%$ & $16,0 \%$ & $18,0 \%$ & $20,0 \%$ & $22,0 \%$ & $24,0 \%$ \\
\hline Sulfidez & $25,0 \%$ & $25,0 \%$ & $25,0 \%$ & $25,0 \%$ & $25,0 \%$ & $25,0 \%$ & $25,0 \%$ & $25,0 \%$ \\
\hline Vol Soda & 38 & 45 & 53 & 61 & 68 & 76 & 83 & 91 \\
\hline Vol sulfeto & 19 & 23 & 27 & 31 & 35 & 39 & 43 & 47 \\
\hline licor madeira & 4 & 4 & 4 & 4 & 4 & 4 & 4 & 4 \\
\hline Vol água & 216 & 204 & 193 & 181 & 170 & 158 & 147 & 135 \\
\hline Aditivo & nd & nd & nd & nd & nd & nd & nd & nd \\
\hline \multicolumn{9}{|l|}{ Aditivo \% as } \\
\hline massa aditivo & 0 & 0 & 0 & 0 & 0 & 0 & 0 & 0 \\
\hline
\end{tabular}




\section{APÊNDICE C}

Deslignificação da madeira ao longo do processo de polpação

A análise de lignina no licor negro consiste na diluição da amostra em água deionizada 1000 vezes e leitura da absorbância a $280 \mathrm{~nm}$ em aparelho espectrofotômetro UV, determinando então, a concentração da lignina dissolvida no licor através da equação (11):

$$
\operatorname{Lignina}(g / l)=0,043 * a b s(280 \mathrm{~nm}) * 1000
$$

